JURNAL KETAHANAN NASIONAL

Vol. 26, No. 2, Agustus 2020, Hal 155-181

DOI:http://dx.doi.org/ 10.22146/jkn.52969

ISSN:0853-9340(Print), ISSN:2527-9688(Online)

Online sejak 28 Desember 2015 di :http://jurnal.ugm.ac.id/JKN

VOLUME 26

No. 2, Agustus 2020

Halaman 155-181

\title{
Sustainable Development Goals: Kebijakan Berwawasan Lingkungan Guna Menjaga Ketahanan Lingkungan Di Kabupaten Bantul Daerah Istimewa Yogyakarta
}

\author{
Etika Khairina \\ Ilmu Pemerintahan Universitas Muhammadiyah Yogyakarta \\ email: etikakhairina@gmail.com \\ Eko Priyo Purnomo \\ Ilmu Pemerintahan Universitas Muhammadiyah Yogyakarta \\ email: eko@umy.ac.id \\ Ajree Ducol Malawani \\ Ilmu Pemerintahan Universitas Muhammadiyah Yogyakarta \\ email: ajree.malawani@g.msuiit.edu.ph
}

Dikirim:28-12-2019; Direvisi:10-08-2020; Diterima:29-08-2020

\begin{abstract}
Maintaining vital contributions and protecting ecosystems to maintained environmental resilience was a supported development concept which was one of the goals agreed by UN countries for the lives of future generations (SDGs). The purpose of this paper was to studied the biodiversity in Bantul Regency, and analyzed its policies and management in conserving biodiversity and protecting the function of ecosystems to supported environmental security by the Bantul Regency government.

The method used was qualitative, data collection using from online interviews with officials of the environmental service, search of the official website of the Department of the Environment, some research literature, online media, etc.

The results showed that the Bantul district government had applied the concept of sustainable development in managing biodiversity in Bantul, animal breeding, turtle conservation, maintained mangrove ecosystems by conserving reserves, preserving functionsare concrete steps that implemented in protecting biodiversity for the benefit of future generations. The Bantul Regency Government had succeeded in achieving an environmentally sound policy by preserving the amount of diversity in Bantul by providing control over the use of natural resources in Bantul so that environmental security was maintained.
\end{abstract}

Keywords: Sustainable Development Goals (SDG's); Biodiversity; Ecosystem; and Environmental Resilience.

\begin{abstract}
ABSTRAK
Mempertahankan kontribusi biologis, melindungi ekosistem guna mendukung ketahanan lingkungan merupakan salah satu konsep pembangunan berkelanjutan (sustainable development goals, SDG's). Tujuan tulisan ini adalah untuk mempelajari keanekaragaman hayati di Kabupatun Bantul, serta menganalisis kebijakan serta
\end{abstract}


Etika Khairina, Eko Priyo Purnomo, Ajree Ducol Malawani -- Sustainable Development Goals: Kebijakan Berwawasan Lingkungan Guna Menjaga Ketahanan Lingkungan Di Kabupaten Bantul

Daerah Istimewa Yogyakarta

pengelolaannya dalam menjaga keanekaragaman hayati dan melindungi fungsi ekosistem untuk mendukung ketahanan lingkungan Kabupaten Bantul.

Penelitian ini merupakan penelitian kualitatif. Data diperoleh berdasarkan hasil wawancara secara online kepada pejabat dinas lingkungan, pencarian situs web resmi Dinas Lingkungan Hidup Kabupaten Bantul, yang kemudian data pendukung diperoleh dari jurnal hasil penelitian, media online dan lain-lain.

Hasil penelitian menunjukkan bahwa untuk menjaga ketahanan lingkungan Pemerintah Kabupaten Bantul telah menerapkan konsep pembangunan berkelanjutan dalam pengelola keanekaragaman hayati dan fungsi ekosistemnya. Kebijakan dan strategi dalam melindungi flora dan fauna daerah, pengembangbiakan hewan, konservasi penyu, dan memelihara ekosistem mangrove dengan cara konservasi pencadangan, pelestarian fungsi adalah langkah konkret yang diterapkan untuk melindungi keanekaragaman hayati dan fungsi ekosistemnya demi kehidupan generasi mendatang. Pemerintah Kabupaten Bantul telah berhasil mengimplementasikan kebijakan dan strategi pembangunan daerah yang berwawasan lingkungan dengan melindungi sejumlah keanekaragaman hayati serta menjaga fungsi ekosistemnya, dengan memberikan kontrol yang baik dan bertahap, sistematis, dan terpadu terhadap pemanfaatan sumberdaya alam yang ada di Kabupaten Bantul, sehingga ketahanan lingkungan tetap terjaga dan berkesinambungan.

Kata Kunci: Pembangunan Berkelanjutan (SDG’s); Keanekaragaman Hayati; Ekosistem; dan KetahananLingkungan.

\section{PENGANTAR}

Menurunnya tingkat keanekaragaman hayati dan rusaknya fungsi ekosistem menyebabkan sejumlah masalah yang serius dan ancaman pada kehidupan manusia. Faktanya sejumlah aktivitas manusia memberikan tekanan terhadap lingkungan, sehingga berpotensi terjadinya degradasi lingkungan dan rusaknya fungsi ekosistem, baik di daratan, laut yang berakibat pada kerugian yang sangat besar dalam kehidupan (Mubarok dkk., 2019; Rahadian, 2016; Rosana, 2018; Temel dkk, 2018). Aktivitas penebangan hutan secara liar dan membabibuta dan tidak memperhatikan aturan yang berlaku, mengakibatkan rusaknya lahan, berkurangnya keanekaragaman hayati, menurunya fungsi ekosistem, pola iklim yang berubah-ubah, menipisnya lapisan ozon, efek rumah kaca, pemanasan global, longsor, dan banjir. Fenomena ini menyebabkan tingkat keterancaman sumberdaya alam yang tinggi, sehingga ketahanan lingkungan dapat menurun.

Besar kemungkinan Perubahan yang terjadi pada lingkungan dan sekitarnya dipengaruhi oleh tindakan dan aktivitas manusia, seperti aktivitas pembangunan mengingat lingkungan sangat rentan pada tekanan dan perubahan yang terjdi secara alami maupun fisik sehingga kualitas lingkungan mengalami penurunan.

Alam dan lingkungan memiliki hubungan yang sangat erat dengan manusia. Manusia melangsungkan kehidupannya bergantung dari pemanfaatan keanekaragaman hayati yang berhubungan dengan sumberdaya alam seperti: tanah, air, udara, hutan, dan lainnya (Diz dkk, 2018; García-Márquez dkk., 2017; Tristyana, 2018; Yustitianingtyas dkk., 2018). Menurut Isbell dkk, (2017), keanekaragaman hayati merupakan istilah yang dipakai untuk memberikan gambaran berbagai macam bentuk kehidupan di permukaan bumi, interaksi di antara makhluk hidup dan lingkungannya. Interaksi tersebut akan merujuk pada keseluruhan aspek kehidupan, ekonomi, sosial, lingkungan, pengetahuan, etika, dan keterkaitan satu aspek dengan aspek lainnya. Secara global, hal ini menjadi isu sangat penting di seluruh dunia.

Menurut United Nasion (dalam www. un.org/sustainabledevelopment, 2019), sebanyak 2,6 miliar manusia bergantung pada tanah, dengan 52\% lahan (tanah) dipergunakan untuk pertanian. Setiap tahunnya ada sekitar 12 juta hektar dan 23 hektar per menit 
tanah yang hilang dan 30/50 kali lipat kesuburan tanah hilang karena penggurunan atau penggundulan lahan dan kekeringan, sementara $80 \%$ makanan manusia diperoleh dari tanaman. Hampir sebanyak 7.000 spesies hewan dan tumbuhan masuk dalam daftar perdagangan illegal dari 120 negara melalui tindakan perburuan illegal dan perdagangan satwa liar. Sebanyak kurang lebih $3 / 4$ dari luas permukaan bumi, yaitu sekitar 3 miliar manusia bergantung kepada keanekaragaman hayati, baik di lautan, laut, maupun pesisir sebagai mata pencaharian mereka; dan lautan menyerap sekitar 30\% karbon dioksida yang dihasilkan oleh aktivitas manusia.

Kondisi tersebut menunjukkan bahwa permasalahan utama pada lingkungan dipengaruhi manusia dalam pemanfaatan sumber daya alam untuk memenuhi kebutuhan. Oleh sebab itu, dibutuhkan kebijakan khusus dan strategi untuk mengatur dan membatasi tindakan yang dapat merugikan alam dan lingkungan. Tergerusnya sumberdaya alam, khususnya terancamnya keanekaragaman hayati, dan rusaknya fungsi ekosistem di daratan, laut atau lautan, sangat erat kaitannya dengan ketahanan lingkungan dan keberlangsung kehidupan manusia pada masa yang akan datang (Kopnina, 2017; Ali dkk, 2018). Menyelamatkan keanekaragaman hayati dan melindungi fungsi ekosistemnya telah menjadi kesepakatan dunia (PBB) dan menetapkannya sebagai salah satu misi Sustainable Develpoment Goals (SDG's), untuk melestarikan dan memanfaatkan sumberdaya alam, baik di daratan, dan lautan secara berkelanjutan, berlangsungnya kehidupan sekarang, besok hingga nanti generasi selanjutnya, serta meningkatkan perekonomian atau kesejahteraan hidup masyarakat.
Sejatinya lingkungan penting dilestarikan sebagai usaha untuk meningkatkan kualitas kehidupan manusia. Kekayaan sumberdaya alam dapat dimanfaatkan sebagaimana mestinya dan tidak over-ekploitasi, dengan tetap berorientasi kepada kepentingan generasi yang akan datang, dan tidak merusak fungsi lingkungan. Menurut Setyaningrum (2017) globalisasi mendorong terjadinya sejumlah tindakan yang dapat merugikan berlangsungnya kehidupan, salah satunya menurunnya keanekaragaman hayati akibat kerusakan dan kepunahan.

Indikasi penurunan jumlah keanekaragaman hayati berpengaruh langsung terhadap kebutuhan mendesak dalam perencanaan dan pengelolaan lingkungan secara terpadu, sehingga dampaknya berpengaruh pada aspek lainnya, seperti lingkungan fisik dan sosial ekonomi. Faktanya rusaknya lingkungan berkaitan erat dengan masalah kemiskinan dan tingkat pertumbuhan ekonomi.

Selanjutnya yang tidak dapat ditepikan ialah pembangunan yang tidak memiliki tahapan berfikir tidak berorientasi jangka panjang bahkan mengabaikan lingkungan sehingga pemangunan dapat memberikan pengaruh yang cukup besar tergadap lingkungan. Dampak dari kebijakan pembangunan tidak mempertimbangkan aspek kelestarian serta fungsi lingkungan (ekosistem), ialah salah satu faktor pemicu bencana tanah longsor dan banjir, yang hampir melanda sejumlah kota di Indonesia pada setiap musim penghujan.

Salah satu daerah yang mengalami sejumlah fenomena alam yang diakibatkan oleh rusaknya lingkungan ialah Kabupaten Bantul DIY. Berdasarkan penjelasan dari Peraturan Daerah Kabupaten Bantul No 12 Tahun 2015 tentang Perlindungan dan Pengelolaan 
Etika Khairina, Eko Priyo Purnomo, Ajree Ducol Malawani -- Sustainable Development Goals: Kebijakan Berwawasan Lingkungan Guna Menjaga Ketahanan Lingkungan Di Kabupaten Bantul

Daerah Istimewa Yogyakarta

Lingkungan Hidup, bahwa meningkatnya berbagai usaha dan kegiatan masyarakat menyebabkan tingkat pembangunan sangat dinamis, sehingga berakibat pada perubahan ekologi.

Dari hasil inventarisasi permasalahan lingkungan hidup di Bantul ialah pencemaran air tanah, pencemaran udara, kerusakan lahan yang disebabkan penambangan galian lobang C, abrasi pantai, permasalahan sampah, alih fungsi lahan dan menurunnya tingkat keaneka ragaman hayati. Kemudian merujuk pada Salah satu elemen ketahanan nasional ialah Sumberdaya alam seperti potensi sumberdaya alam hewani, nabati dan tambang, kemampuan mengekplorasi alam, pemanfaatan yang memperhitungkan masa depan dan lingkungan hidup. Oleh karena itu pemerintah Kabupaten Bantul telah menyusun langkah strategis dan berpedoman pada konsep pembangunna berkelanjutan, maka untuk menjaga ketahanan lingkungan di Kabupaten Bantul.

Wujud dari konsep pembangunan berkelanjutan di antaranya ialah menjaga keseimbangan antara fungsi ekologi, ekonomi (ecological and economics balance) (Gordon dkk, 2017; Liu dan Côté, 2017; Budianto, 2008 ). Seperti yang disampaikan oleh (Rosana (2018), dan Junyuan dkk. (2019), bahwa dimensi lingkungan dalam pembangunan yang berkelanjutan perlu diperhatikan, pembangunan tidaklah serta merta dilakukan tanpa memikirkan dan melihat aspek lainnya yaitu lingkungan dan kehidupan makhluk hidup lainnya. Menerapkan pembangunan berwawasan lingkungan adalah salah satu usaha mempertahankan fungsi lingkungan untuk tetap dapat dimanfaatkan pada masa yang akan datang.

Pemerintah Kabupaten Bantul telah menaruh sikap pesimis dalam menanggulangi kerusakan lingkungan, terlebih lagi setelah Badan Lingkungan Hidup Kab Bantul dan Wahana Lingkungan Indonesia (Walhi) mencatat kasus lingkungan hidup yang mengalami kerusakan di Kabupaten Bantul, seperti sejak tahun 2013 di Kecamatan Pajangan dan Pleret marak melakukan penambangang batu pada wilayah perbukitan, dan apabila aktivitas ini dilakukan secara berkepanjangan maka akan merusak keseimbangan ekosistem di sekitarnya dan memicu potensi bencana alam.

Kabupaten Bantul telah melakukan beberapa langkah strategis untuk tetap menjaga dan melestarikan fungsi lingkungan seperti upaya konservasi, perbaikan fungsi ekosistem, dan memanfaatkan ekosistem untuk meningkatkan perekonomian masyarakat setempat (Ardiyansari dkk, 2019; Fatimah, 2018; Yahya, 2016). Peraturan daerah No 12 Tahun 2015 tentang Pengelolaan dan Perlindungan Lingkungan hidup, Surat Keputusan Bupati Bantul Nomor 284 Tahun 2014 tentang Pencadangan Kawasan Konservasi Taman Pesisir merupakan kebijakan Pemerintah Daerah Kabupaten Bantul, dalam memperbaiki pembangunan daerah berbasis lingkungan dalam konsep pembangunan yang berkelanjutan.

Menetapkan kawasan konservasi pada sejumlah ekosistem menjadi salah satu langkah untuk melestarikan biodiversitas dan fungsi ekosistem, Konservasi dapat menguatkan posisi dan fungsi suatu kawasan sebagai ekosistem yang harus dilindungi, salah satu langkah mencapai ketahanan lingkungan ialah dengan manfaat kawasan konservasi sehingga dapat meningkatkan nilai ekonomi kawasan untuk menunjang kesejahteraan masyarakat.

Menurut Zhang dkk. (2017), Arianti dan Satlita (2018), Fatimah (2018a), dan 
Tristyana (2018), konservasi kawasan obyek wisata dan kawasan lain yang sering dikunjungi sebagai obyek penelitian dan wisata, akan meningkatkan nilai ekonomi kawasan. Mengoptimalkan potensi konservasi ekosistem dan menjaga kelestarian fungsi lingkungan sangat penting, untuk mendukung pembangunan yang berkelanjutan (Ferrier dkk., 2019; Junyuan dkk., 2019).

Merealisasikan hal tersebut pemerintah membuat konsep kebijakan peduli lingkungan. Pemerintah Daerah dan berbagai stakeholder lainnya mulai bertindak ke arah perbaikan lingkungan melalui berbagai program, seperti: pengelolaan persampahan melalui bank sampah dan kegiatan 3R, atau kegiatan konservasi ekosistem, seperti: ekosistem mangrove, padang lamun, terumbu karang, dan lainnya. Dalam rangka pengelolaan suatu ekosistem Pemerintah Daerah harus didukung oleh masyarakat setempat. Masyarakat adalah subjek utama dalam kegiatan pengelolaan sumberdaya alam, mengingat masyarakat hidup berdampingan langsung dengan alam sehingga merasakan langsung dampak positif dan negatif dari kegiatan pemanfaatan sumberdaya alam.

Kegiatan yang terencana, terpadu dan sistematik untuk meningkatkan kesejahteraan manusia dan menjaga kelestarian fungsi lingkungan, tanpa mengurangi akses dan manfaat untuk generasi yang akan datang menjadi cara pandang atau acuan pemerintah dan masyarakat serta pihak yang terlibat di dalamnya untuk merealisasikan Kebijakan berwawasan lingkungan dan sebagai wujud dari konsep pembangunan berkelanjutan (Sustainable Development Goals).

Konsep pembangunan berkelanjutan sebagai upaya menjaga ketahanan lingkungan diharapkan akan mampu membantu persoalan lingkungan dan keberlangsungnya kehidupan. Kebijakan pembangan berkelanjutan berkaitan dan bertujuan langsung untuk menjaga kehidupan manusia, keseimbangan sumberdaya alam, kelestarian lingkungan. Mengingat sumberdaya alam sebagai bagian atau elemen dari ketahanan nasional, dalam bentuk ketahanan lingkungan. Pembangunan berkelanjutan merupakan agenda politik pembangunan dunia atau pembangunan global (Zhu, 2017). Pemerintah Pusat maupun Pemerintah Daerah menjadi bagian dari pembangunan dunia, sehingga harus sejalan dan menjadi panduan dalam menjaga keberlangsungan dan kelestarian fungsi lingkungan (Setiawati, 2009).

Lingkungan dan ekonomi memiliki hubungan penting dalam pembangunan berkelanjutan. Merujuk pada penjelasan dan pemikiran di atas, maka upaya mewujudkan ketahanan lingkungan di Kabupaten Bantul, dilakukan dengan konservasi atau pelestarian fungsi ekosistem seperti: konservasi ekosistem mangrove, ekosistem penyu, dan berbagai ekosistem di wilayah pesisir. Merupakan strategi yang disiapkan dalam pengelolaan sumberdaya alam dan pelestarian fungsi ekosistem guna mendukung ketahanan lingkungan dalam konsep pembangunan yang berkelanjutan.

Berdasarkan konsep pembangunan berkelanjutan dan Fenomena yang ada di Kabupaten Bantul, maka tulisan ini akan fokus pada "Bagaimanakah hubungan antara Kebijakan Pembangunan Daerah dalam memanfaatkan Sumberdaya Alam untuk menjaga Keanekaragaman Hayati dan Kelestarian Fungsi Ekosistem, sebagai upaya meningkatkan Ketahanan Lingkungan sebagai bagian dari implementasi Pembangunan Berkelanjutan di Kabupaten Bantul, Daerah Istimewa Yogyakarta?" 
Etika Khairina, Eko Priyo Purnomo, Ajree Ducol Malawani -- Sustainable Development Goals: Kebijakan Berwawasan Lingkungan Guna Menjaga Ketahanan Lingkungan Di Kabupaten Bantul

Daerah Istimewa Yogyakarta

Berdasarkan penjelasan pengantar, tulisan ini bertujuan (1). Mempelajari dan mengkaji keanekaragaman hayati dan ekosistemnya yang ada di Kabupaten Bantul secara mendalam. (2).Menganalisis kebijakan dan strategi pengelolaan keanekaragaman hayati dan kelestarian fungsi ekosistem untuk mendukung ketahanan lingkungan, sebagai bagian mewujudkan pembangunan berkelanjutan di Kabupaten Bantul. (3). Mengetahui penerapan pembangunan yang berkelanjutan dalam pengelolaan dan pelestarian lingkungan Kabupaten.

Metode yang digunakan dalam penelitian ini adalah metode survei dengan studi kasus Pembangunan Daerah Berkelanjutan di Kabupaten Bantul. Dengan memperhatikan objek dan fenomenologi untuk menggali data dan menemukan hal-hal mendasar. Seperti yang disampaiakan oleh Mudjia (2017), bahwa studi kasus akan memperoleh peristiwa mendalam, intensif, dan rinci, dari kegiatan, dan peristiwa pada objek tertentu baik perorangan atau organisasi. Rahardjo (2018) menyampaikan pula bahwa fenomenologi yang dimaksud adalah bagaimana mendeskripsikan sesuatu yang dialami melalui indra sendiri.

Jenis data ialah data kualitatif, Data juga akan dianalisis secara kualitatif, Untuk mendapatkan data yang lebih spesifik tentang kebijakan Pemerintah Daerah dalam pengelolaan sumberdaya alam, keanekaragaman hayati dan ekosistemnya dikumpulkan melalui wawancara dan studi literatur sebagai data pendukung. Data yang dikumpulkan dari proses tersebut akan dikelompokkan bedasarkan jenis keanekaragaman hayati kemidian akan dianalisis secara rinci.

Penelitian ini dilakukan terhadap kebijakan Dinas Lingkungan Hidup Kabupaten
Bantul, dengan teknik sampling. Teknik penentuan informan secara purposive sampling terhadap para pegawai di Dinas Lingkungan Hidup Pemerintah Kabupaten Bantul, dengan mendeskripsikan temuan di lapangan (data) dan fakta secara logis, lalu dirumuskan untuk mengambil kesimpulan tentang kebijakan pengelolaan sumberdaya alam untuk mendukung ketahanan lingkungan sebagai bagian implementasi konsep pembangunan berkelanjutan di Kabupaten Bantul.

Penelitian ini didasarkan atas beberapa teori sebagai berikut.

Pertama, pembangunan berkelanjutan. Telah banyak penelitian di Indonesia dan internasional mengenai upaya menyelamatkan/ pelestariankeanekaragaman hayati dan bagaimana melindungi ekosistem dalam tujuan pembangunan berkelanjutan. Menurut Dewi \& Martono (2012); Fukuda-Parr (2016); Hák dkk (2016); Wahyuningsih (2018) Sustainable Development Goals (SDG's) didirikan oleh masyarakat internasional sebagai tindak lanjut berakhirnya program MDGs tahun 2015 digantikan oleh Sustainable Development Goals (SDGs), tulisan masingmasing mengungkapkan pembangunan berkelanjutan mengacu pada peningkatan kualitatif berkelanjutan dalam standar kehidupan masyarakat secara keseluruhan dalam suatu negara/ bangsa.

Menurut Huda (2008) bahwa pembangunan berkelanjutan merupakan pembangunan dalam rangka memenuhi kebutuhan hidup sekarang tanpa merusak kebutuhan hidup generasi mendatang. Pemahaman lain juga disampaikan oleh Siregar (2007) bahwa konsep pembangunan berkelanjutan ialah suatu kebijaksanaan dalam pembangunan, standarnya tidak hanya berfokus pada satu aspek. 
Menurut Nuniek (2015); Prip, (2018); Rees dkk (2018), menyelamatkan keanekaragaman hayati dari ancaman dan melindungi ekosistem di darat dan laut merupakan salah satu bagian dari pembangunan yang berkelanjutan yang telah disetujui PBB dan menjadi salah satu tujuan yang harus diupayakan untuk keberlangsungan kehidupan sekarang dan nanti. Dalam tulisan Keenan dkk, (2019); Rahadian, (2016) tujuan pembangunan berkelanjutan termasuk di dalamnya mengejar pertumbuhan ekonomi dan mempertahankan kesejahteraan rakyat yang berkelanjutan serta kualitas kehidupan manusia dilakukan dengan upaya pemerataan manfaat dan hasil pengelolaan keanekaragaman hayati, dengan menyelamatkan keanekaragaman dan melindungi ekosistem baik di darat dan dilaut.

Kedua, keanekaragaman hayati (Biodiversity) dan lingkungan. Menurut Anggraini, (2018), tantangan utama pembangunan ialah masalah penyediaan makanan. Dalam tulisannya ia menyebutkan masalah utama ialah miskin pengetahuan, sulit menemukan potensi, meninggalkan peluang di masa depan sebagai target baru yang menyeluruh untuk semua segala bentuk kemiskinan, melawan ketidaksetaraan dan mengatasi perubahan iklim akan digerakkan oleh negara. Hal tersebut sejalan dengan penyampaian Junyuan dkk. (2019) dalam tulisannya bahwa keanekaragaman hayati adalah kekayaan alam yang dapat dimanfaatkan di masa sekarang dan di masa yang akan datang, sedangkan penyediaan makanan adalah salah satu tantangan pembangunan berkelanjutan.

Biodiversitas/keanekaragaman hayati merupakan kekayaan alam yang sangat dibutuhkan dan bermanfat untuk masa depan (Diz dkk., 2018). Keanekaragaman hayati mendatangkan banyak manfaat bagi manusia, termasuk pengaturan iklim dan produksi kayu di hutan, ternak di padang rumput dan ikan di ekosistem perairan (Moore, dkk. 2015; Rees, dkk, 2018). Penyediaan makanan dan air, pemeliharaan habitat dan keanekaragaman hayati, dan penyimpanan dan penyerapan karbon dianggap masing-masing memberikan kontribusi kepada kehidupan manusia (Wood dkk, 2018). Menurut Rosana (2018) bahwa globalisasi menjadi faktor pendorong adanya tindakan overeksploitasi kekayaan alam baik di darat maupun di laut yang menjadi ancaman berlangsungnya kehidupan.

Permasalahannya kekayaan alam did arat dan di laut erat hubungannya dengan kehidupan manusia, alam menawarkan bahan dasar yang sangat dimanfaatkan oleh manusia seperti, makanan, obat-obatan, pakaian sehingga hal inilah yang mendasari adanya tindakan pemanfaatan secara berlebih (Eastwood dkk, 2016). Kemudian hal yang sama disampaikan Gull dkk, (2017) dalam penelitiannya bentuk nyata dari overeksploitasi yang dilakukan terhadap alam ialah adanya efek domino bagi lingkungan dan bumi secara keseluruhan. Menurut Fatimah, (2018) bahwa dampak dari globalisasi tersebut dibutuhkan peran negara dalam menciptakan batasan-batasan yang kuat untuk melindungi kekayaan alam yang ada dan dapat dimanfaatkan sesuai kebutuhan demi keberlangsungan kehidupan ke depannya.

Ketiga, ketahanan lingkungan.

Kebijakan lingkungan lahir dari kesadaran manusia terhadap lingkungan sekitarnya dan keinginan untuk melestarikan serta menjaga manfaat sumber daya alam secara nasional dan global (Setiawati, 2009). Ada beberapa cara atau metode serta pendekatan yang dapat dipakai dalam melestarikan keanekaragaman hayati yng juga sebagai 
Etika Khairina, Eko Priyo Purnomo, Ajree Ducol Malawani -- Sustainable Development Goals: Kebijakan Berwawasan Lingkungan Guna Menjaga Ketahanan Lingkungan Di Kabupaten Bantul

Daerah Istimewa Yogyakarta

usaha dalam pengelolaan lingkungan untuk mewujudkan pembangunan berkelanjutan.

Menurut Drakel, (2010) bahwa pengelolaan lingkungan dapat dipahami sebagai langkah terpadu melestarikan keanekaragaman hayati di antaranya mulai dari penataan, kebijakan, pemanfaatan, pengembangan, pemeliharaan, pemulihan, pengawasan dan pengendalian. Dalam Tulisan Ali dkk, 2018; Gordon dkk. (2017); Nuniek, (2015); Prip, (2018) bahwa untuk mewujudkan pembangunan berkelanjutan, meningkatkan dan melindungi ekosistem ialah dengan pengelolaan hutan, melakukan pendekatan partisipatif dengan teknik fokus pada kelompok.

Seperti yang disampaikan Hardiyanti dan Aminah (2019) salah satu cara mewujudkan pembangunan berkelanjutan, untuk melestarikan kawasan hutan di Pulau Jawa sehingga dapat memenuhi kebutuhan masyarakat saat ini dan mendatang, membangun model pengelolaan hutan dengan menyertakan peran masyarakat sebagai masyarakat adat, dan penerima delegasi.

Lain halnya di Banyuwangi, menurut Setyaningrum, (2017) dalam penelitiannya ekosistem di Banyuwangi dalam melestarikan ekosistem mangrove pemerintah bekerja sama dengan Ramsar Regional Centre- East Asia Wetland Fund (RRC-EA WF) untuk memberdayakan masyarakat dan menggunakan beberapa metode pemberdayaan mulai dari pelatihan, pembibitan, pendidikan dan survei rute mangrove yang sesuai. Mengembangkan kawasan Ekowisata mangrove dapat menjadi salah satu alternatif dalam menjaga ketahanan lingkungan (Ardiyansari dkk, 2019).

Keanekaragaman hayati memiliki nilai ilmiah salah satu pendekatan pelestarian mendasar yang dapat meningkatkan ekosistem ialah pendekatan geokonservasi (upaya pelestarian alam yang lebih luas, integrase solusi dan berbasis alam) (Gordon dkk, 2017). Namun demikian menurut Isbell dkk. (2017) bahwa goekonservasi secara umum belum terintegrasi dengan baik dalam kebijakan konservasi alam yang didominasi oleh keanekaragaman hayati dalam mempengaruhi kebijakan dan praktek pengelolaan lingkungan dan melestarikan sumberdaya bumi.

Menurut Yustitianingtyas dkk, (2018) terancamnya ekosistem terumbu karang di pasir putih Situbondo ialah salah satu faktor ketahanan pangan nasional sehingga pemerintah pusat dan daerah perlu melakukan upaya-upaya pengeloaan terumbu karang sehingga ketahanan pangan dapat dipertahankan. Menurut Arlis, dkk, (2018) bahwa wilayah Bagan Serdang Medan mengadopsi pendekatan pengelolaan konservasi dan pelestarian mangrove berbasis collaborative management dan community based tourism pada kelompok masyarakat sebagai upaya revitalisasi fungsi ekologi dalam ekosistem hutan mangrove sebagai wujud pembangunan berkelanjutan.

Menurut Moore dkk. (2015) bahwa metode manta tow adalah salah satu metode yang digunakan Kepulauan Banggai untuk mempertahankan ekosistem terumbu karang yang sangat terbatas. Hal tersebut sejalan dengan Wahyuningsih, (2018), menurutnya sebagai kawasan konservasi perairan aspek sosio-ekonomi menjadi aspek yang perlu diperhatikan dalam mewujudkan pola pembangunan yang berkelanjutan. Konsep pemasaran hijau dapat digunakan untuk melindungi lingkungan dan dapat dijadikan sebagai sarana dalam mewujudkan pembangunan berkelanjutan konsep ini biasanya dipakai di bidang ekonomi dan 
bisnis, pola pembangunan tersebut diyakini tidak menyebabkan kerusakan lingkungan (Widyastuti, 2019).

Di samping itu berapa negara di luar Indonesia (Internasional) juga melakukan hal yang sama terhadap beberapa ekosistem seperti menurut García-Llorente dkk, (2018) melakukan penelitian di dua kawasan lindung Spanyol meliputi lahan basah dan gunung mediterania. Menurutnya konservasi ialah strategi mempertahankan ekosistem, namun implementasi kebijakan dalam konservasi masih tahap awal karena cendrung mengabaikan kepentingan masyarakat lokal sehingga ekosistem perlu perhatian lanjut, seperti menyediakan layanan ekosistem untuk meningkatkan kepentingan sosial dalam pengelolaan kawasan lindung tersebut.

Mempertahankan keanekaragaman hayati dan ekosistem di Cina (Tiongkok) dan mencapai tujuan pembangunan yang berkelanjutan, maka hal yang dilakukan ialah mengurangi aktivitas manusia dengan tujuan menutup celah politis dan menciptakan kategori baru kawasan konservasi global mengingat banyaknya habitat dan spesies yang terancam (Xu dkk, 2017). Medellin, dkk. (2017) menyebutkan bahwa vandalisme dan urbanisasi adalah salah satu ancaman yang dapat merusak ekosistem. Sedangkan di Madagaskar, Andrianandrasana, (2016) menyatakan bahwa Madagaskar memanfaatkan peran CBC dalam melestarikan keanekaragaman hayati dan melindungi ekosistem, temuannya menunjukkan bahwa CBC berhasil menurunkan tingkat frekuensi kebakaran, meskipun intervensi CBC tidak dapat mengurangi kehilangan area hutan, kebakaran disebabkan karena gangguan politik, dan tidak ada control dari desa sekitar hutan.
Menurut Eastwood dkk. (2016) bahwa efek konservasi pada sejumlah keanekargaman hayati dan jasa ekosistem yang mengambil studi kasus di Inggris temuannya menunjukkan bahwa situs yang dilindungi memberikan tingkat layanan ekosistem yang lebih tinggi daripada situs yang tidak dilindungi, letak perbedannya ialah pada budaya dan pengelolaan ekosistem sehingga tetap dapat dilestarikan. Menurut Temel dkk, (2018) bahwa untuk ekosistem yang terancam bisa menggunakan pendekatan monetisasi dalam melestarikan dan melindungi ekosistem tersebut. Kemudian dalam kebijakan dan bisnis valuasi moneter dapat digunakan untuk menilai kesesuaian hasil konservasi keanekaragaman hayati.

Menurut Isbell dkk. (2017) hilang dan berkurangnya keanekaragaman hayati akan menjadi masalah baru bagi pembuat keputusan dan kebijakan. Kebijakan lingkungan perlu memikirkan dampak penting keanekaragaman hayati tidak hanya melihat sebagai output tapi juga sebagai input dari kebijakan. Melihat dari sisi keadilan sosial dan ekologi terkait perlindungan hutan dan melihat apakah eksploitasi hutan berdasarkan model manajerial top-down mendorong distribusi sumberdaya yang tidak merata (Kopnina, 2017). Dibutuhkan fokus dalam menangani kebutuhan sosial dan ekologis sebagai aspek penting dari keadilan lingkungan yang fokus pada aspek sosial dam perlindungan hutan.

Menurut Lin dkk. (2017) bahwa menggunakan pendekatan konservasi untuk melindungi habitat dan ekosistem secara tradisional hanya akan berfokus pada satu habitat saja, oleh karena itu untuk melindungi ekosistem dan habitat perlu melakukan program LISA-Zonation yang melakukan perencanaan konservasi sistematis berdasarkan hasil invest. 
Etika Khairina, Eko Priyo Purnomo, Ajree Ducol Malawani -- Sustainable Development Goals: Kebijakan Berwawasan Lingkungan Guna Menjaga Ketahanan Lingkungan Di Kabupaten Bantul Daerah Istimewa Yogyakarta

Menurut Liu dan Côté, (2017) bahwa pembangunan berkelanjutan jasa ekosistem di Cina, dalam menyelesaikan masalah menipisnya sumberdaya dan pencemaran lingkungan maka pemerintah Cina memposisikan circular economy sebagai strategi pemulihan jasa ekosistem. Sedangkan Peh dkk, (2016) mengambil kawasan lindung Himalaya di Nepal untuk membandingkan terlindungnya atau kurang terlindungnya jasa ekosistem dapat dilakukan dengan pendekatan praktis dengan Toolkit for Ecosystem Service Site-based Assessment (TESSA).

Menurut Rees dkk. (2018) bahwa untuk mengimplementasikan tujuan yang menekankan pada konteks ekonomi dan sosial dari pembangunan global harus mengintegrasikan pembangunan berkelanjutan dengan pengetahuan dan kemajuan dalam rangka memperkuat upaya global untuk konservasi keanekaragaman hayati. Kemudian Le, dkk, (2016) mengambil lokasi di Tam Dao Nasional. Studi ini meneliti preferensi orangorang di Hanoi, Vietnam, untuk melestarikan ekosistem dan melindungi O. tamdaoensis, menawarkan wawasan penting bagi para pembuat kebijakan yang tertarik melibatkan orang dalam konservasi keanekaragaman hayati dan meningkatkan kesadaran sosial tentang jasa ekosistem.

Menurut Zhang dkk. (2017) bahwa untuk meningkatkan efisiensi pelestarian ekosistem di Tiongkok, dilakukan dengan pendekatan struktural, strategi praktis untuk memperbaiki konflik administrasi, meningkatkan manajemen masyarakat, alokasi pendanaan konservasi yang transparan, memperkuat pengawasan dan mekanisme hukuman untuk kegiatan yang merusak, dan meningkatkan kapasitas koordinasi untuk meningkatkan koordinasi. Menurut Purnomo dan Nurmandi,
(2016) bahwa untuk mengelola sumber daya secara berkelanjutan dibutuhkan pengaruh dari institusi lokal karena organisasi lokal lebih mampu menyesuaikan dan bekerja mengelola sumberdaya alam milik bersama. Hal yang sama disampaikan Budianto, (2008) berbagai komponen mulai dari pemerintah, wakil rakyat, anggota masyarakat organisasi dan non organisasi harus sama-sama mempunyai komitmen melestarikan lingkungan mengingat pengelolaan dan pengawasan salah satu faktor yang menentukan berhasilnya ketahanan lingkungan. Arianti dan Satlita, 2018b) menegaskan dalam menjaga keanekaragaman hayati baik dengan cara konservasi untuk memelihara ekosistem pemerintah harus bekerjasama dengan pemerintah dengan tujuan membangun kesadaran bersama untuk arah pengembangan.

Mengelola sumber daya alam dengan konsep pembangunan berkelanjutan bertujuan menjaga ketahanan lingkungan. Menurut Winarna, dkk, (2020) bahwa menjaga ketahanan wilayah maupun lingkungan, pemerintah perlu menerapkan mekanisme sinergitas kelembagaan yang dilaksanakan di daerah berupa strategi memberdayakan masyarakat. Penguatan lainnya disampaikan oleh Candra dkk. (2020) bahwa penguatan kewarganegaraan ekologis dapat mewujudkan ketahanan lingkungan seperti kegiatan tanam pohon, pengelolaan sampah.

\section{PEMBAHASAN}

Pembangunan Berwawasan Lingkungan Sebagai Bagian Dari Upaya Meningkatkan Ketahanan Lingkungan

Pembangunan berwawasan lingkungan merupakan pembangunan berkesinambungan dengan tujuan peningkatan terhadap mutu hidup masyarakat dengan pengelolaan 
sumberdaya alam dengan sebaik mungkin. Meningkatnya kesejahteraan masyarakat merupakan sasaran pembangunan baik itu yang sifatnya alamiah, kimia maupun secara fisik, sifat pembangunan tersebut dapat menimbulkan pengaruh yang cukup besar terhadap lingkungan. Pemeliharaan untuk kelestarian sangat berpengaruh untuk mengurangi tekanan terhadap keberadaan keanekaragaman hayati melalui program konservasi. Menanggulangi masalah kerusakan yang terjadi pada lingkungan dengan metode konservasi dapat dipahami sebagai usaha pengelolaaan sumberdaya alam berwawasan lingkungan hidup yang berkelanjutan. Kegiatan konservasi bisa dimulai dari memelihara lingkungan keluarga, masyarakat sampai bangsa (Peh dkk, 2016).

Usaha yang dilakukan secara sadar dengan menggali hasil alam dan tidak merusak sumberdaya alam lainnya merupakan hakikat dari pengelolaan sumber aya alam, sehingga dalam penggunaanya harus memiliki pedoman sebagai panduan dalam pemeliharaan dan perbaikan kualitas dari sumberdaya alam tersebut. Melonjaknya produksi dan perubahan globalisasi dan perkembanagan kemajuan sering kali mengorbankan lingkungan sehingga menyebabkan kerusakan lingkungan. Lingkungan yang tercemar akan berdampak buruk bagi kelanjutan dan keberadaan sumberdaya alam yang akhirnya dapat menurunkan kehidupan masyarakat, oleh karena itu pengelolaan sumberdaya alam perlu memperhatikan keserasian serangkaian aktivitas/kegiatan manusia dengan lingkungan. Keserasian lingkungan merupakan proses pembentukan lingkungan dengan interaksi sekitarnya, termasuk dalam pengelolaannya sehingga ia dapat seimbang. Kesesuian lingkungan dan pengelolaanya perlu dikonsepkan dengan konsep berkelanjutan supaya pelestarian terhadap lingkungan dapat dilakukan secara terus menerus tanpa menghambat kemajuan.

Kabupaten Bantul mempunyai potensi sumberdaya alam seperti satwa dan vegetasi tanaman mangrove yang memiliki keindahan alam hayati. Potensi dan keindahan alam di Bantul dapat dikembangkan dan dimanfaatkan sebagai instrumen atau alat untuk mengembangkan ilmu pengetahuan seperti pendidikan dan penelitian yang dapat mendukung ketahanan lingkungan. Konservasi adalah salah satu pendekatan yang dipilih pemerintah Kabupaten Bantul sebagai usaha pelestarian sumber daya alam hayati dan ekosistemnya, yang dilakukan melalui program rehabilitasi, restorasi dan metode lainnya yang sesuai dengan perkembangan ilmu pengetahuan dan teknologi. Alternatif tersebut secara jelas diatur dalam Peraturan Daerah Bantul No 12 Tahun 2015 tentang Perlindungan dan Pengelolaan Lingkungan Hidup. Langkah selanjutnya menjaga ketahanan lingkungan di Kabupaten Bantul ialah penangkaran tanaman dan satwa liar. Pemerintah Kabupaten Bantul sejak 2009 telah mendorong penangkaran flora dan fauna yang berstatus terancam punah dan berlimpah untuk dilestarikan di habitat alami masing-masing. Penangkaran bertujuan untuk pengembangbiakan dan pembesaran satwa dengan tetap mempertahankan keaslian jenisnya. Secara teknis penangkaran diatur dalam Peraturan Bupati Nomor 24 tahun 2016 tentang Konservasi Burung dan Ikan, Keputusan Bupati Bantul pada tahun 2014 tentang Reservasi Kawasan Konservasi Taman Pesisir.

\section{Keanekaragaman Hayati Dan Ekosistemnya Di Kabupaten Bantul}

Dampak pembangunan terhadap lingkungan bukan hanya masalah lokal 
Etika Khairina, Eko Priyo Purnomo, Ajree Ducol Malawani -- Sustainable Development Goals: Kebijakan Berwawasan Lingkungan Guna Menjaga Ketahanan Lingkungan Di Kabupaten Bantul

Daerah Istimewa Yogyakarta

tetapi dunia, sebagian besar dunia merasakan masalah efek kemajuan pada lingkungan. Penciptaan pembangunan berkelanjutan di Indonesia mengingatkan kita bahwa penting untuk melaksanakan pembangunan berwawasan lingkungan untuk kehidupan yang lebih baik. tersebarnya lingkungan yang rusak secara ekologis menimbulkan banyak fakta seperti banjir, kerusakan lahan, hilangnya keanekaragaman hayati, perubahan pola iklim, menipisnya lapisan ozon, efek rumah kaca, pemanasan global, tanah longsor. Kerusakan lingkungan adalah salah satu faktor yang menyebabkan kegagalan Indonesia mempertahankan lingkungan dan tidak sejalan dengan konsep pembangunan berkelanjutan.

Pembangunan berhubungan erat dengan lingkungan dan sangat mempengaruhi lingkungan, mengingat Lingkungan menjadi pemasok sumberdaya alam sebagai sumber kebutuhan manusia, ketahanan lingkungan, dan kemudian lingkungan menyediakan sumberdaya manusia sebagai subjek dalam pembangunan. Pembangunan akan membawa dampak dan risiko bagi ekosistem. Karena itu kegiatan pembangunan harus ramah lingkungan untuk pembangunan berkelanjutan. Pengelolaan keanekaragaman hayati dan ekosistem tidak dapat dipisahkan dari dorongan untuk kebutuhan ekonomi. Penggunaan sumberdaya alam termasuk keanekaragaman hayati dan penggunaan ekosistem oleh pemerintah tidak hanya memiliki satu target, dan pemanfaatannya harus berdampak pada banyak aspek (Medellin dkk, 2017).

Tujuan menggunakan sumberdaya alam berdasarkan keputusan pemerintah seperti pertumbuhan ekonomi, menjaga keindahan lingkungan. Seperti yang disampaikan Arianti dan Satlita, (2018a); Fatimah, (2018), bahwa kebutuhan ekonomi akan mendorong sebagian besar kebijakan, terutama pengelolaan keanekaragaman hayati. Pengelolaan ekosistem dan keanekaragaman hayati akan mengacu pada peraturan pemerintah dalam implementasinya. Pengembangan atau pemanfaatan sumberdaya alam berpotensi menyebabkan kerusakan dan mengancam pelestarian keanekaragaman hayati.

Pembangunan yang berwawasan lingkungan harus memperhatikan perencanaan tata ruang, lingkungan harus menyertai kegiatan yang berdampak pada lingkungan, dan pengembangan dan rehabilitasi lahan harus dilakukan untuk mengembangkan konservasi kawasan lindung (Huda, 2008). Kondisi yang dipertimbangkan atau diprioritaskan oleh Kabupaten Bantul dalam perencanaan pembangunan, memberikan dampak yang signifikan terhadap daerah/ masyarakat di masa depan, sedangkan isu-isu strategis yang dirancang terkait dengan lingkungan di Kabupaten Bantul adalah perubahan fungsi lahan, pengelolaan limbah padat, optimalisasi ruang hijau di wilayah perkotaan dan strategis, migrasi bencana, polusi lingkungan.

Kabupaten Bantul memiliki kawasan lindung yang ditetapkan sebagai kawasan yang harus dijaga keberadaannya. Melindungi dan melestarikan sumberdaya alam, sumber daya bantuan atau buatan dan nilai budaya untuk keberlangsungan pembangunan yang berkelanjutan. Pada tahun 2009 pembentukan kawasan lindung mulai difikirkan pemerintah Kabupaten Bantul, walaupun pada Tahun 2009 baru dilakukan tahap pemantapan data perencanaan kawasan lindung. Dari data tersebut akan diperoleh lokasi yang tepat dan akurat dalam penyusunan perencanaan, pengelolaan kawasan lindung. Lokasi yang ditetapkan sebagai kawasan lindung Kabupaten Bantul dapat dilihat pada tabel 1. 
Tabel 1

Persebaran Kawasan Lindung Di Kabupaten Bantul

\begin{tabular}{|c|c|c|c|c|c|c|}
\hline \multirow[b]{2}{*}{$\begin{array}{l}\text { Kecamatan } \\
\text { / Desa }\end{array}$} & \multicolumn{5}{|c|}{ Luas Kawasan Lindung (Ha) } & \multirow[b]{2}{*}{$\begin{array}{l}\text { Total Luas } \\
\text { (Ha) }\end{array}$} \\
\hline & $\begin{array}{l}\text { Sempadan } \\
\text { Pantai }\end{array}$ & $\begin{array}{c}\text { Sempadan } \\
\text { Sungai }\end{array}$ & $\begin{array}{c}\text { Kawasan } \\
\text { Mataair }\end{array}$ & $\begin{array}{c}\text { Cagar Alam dan } \\
\text { Budaya }\end{array}$ & $\begin{array}{l}\text { Rawan Erosi } \\
\text { dan Longsor }\end{array}$ & \\
\hline \multicolumn{7}{|l|}{ Kec. Sedayu } \\
\hline 1. Desa. Argorejo & & & 0,0019 & 0,0015 & 5 & 5,0034 \\
\hline 2. Desa. Argodadi & & & 0,0036 & - & 5 & 5,0036 \\
\hline 3. Desa. Argomulyo & & & 0,0024 & - & - & 0,0024 \\
\hline 4. Desa. Argosari & & & 0,0009 & - & - & 0,0009 \\
\hline Jumlah & & & 0,0088 & 0,0015 & 10 & 10,0103 \\
\hline \multicolumn{7}{|l|}{ Kec. Pajangan } \\
\hline 1. Desa.Triwidadi & & & 0,0116 & 0,0044 & 1,5 & 1,516 \\
\hline 2. Desa. Sendangsari & & & 0,5043 & 0,0003 & 1,5 & 2,0046 \\
\hline 3. Desa. Guwosari & & & 0,0034 & 0,0024 & - & 0,0058 \\
\hline Jumlah & & & 0,5193 & 0,0071 & 3 & 3,5264 \\
\hline \multicolumn{7}{|l|}{ Kec. Kasihan } \\
\hline 1. Desa.Bangunjiwo & & & 0,0111 & 0,2068 & - & 0,2179 \\
\hline 2. Desa.Ngestiharjo & & & 0,0016 & - & - & 0,0016 \\
\hline 3. Desa.Tamantirto & & & 0,0012 & - & 5 & 5,0012 \\
\hline Jumlah & & & 0,0139 & 0,2068 & 5 & 5,2207 \\
\hline \multicolumn{7}{|l|}{ Kec. Imogiri } \\
\hline 1. Desa. Selopamioro & & & 0,0203 & 2,004 & 11 & 13,0243 \\
\hline 2. Desa.Imogiri & & & 0,0151 & - & - & 0,0151 \\
\hline 3. Desa.Wukirsari & & & - & 27,775 & - & 27,775 \\
\hline 4. Desa.Sriharjo & & & - & - & - & 0 \\
\hline Jumlah & & & 0,0354 & 27,775 & 11 & 40,8144 \\
\hline \multicolumn{7}{|l|}{ Kec. Kretek } \\
\hline 1. Desa.Parangtritis & 120 & & 0,0015 & 0,35655 & & \\
\hline 2. Desa.Tirtoharjo & 40 & & - & - & & \\
\hline 3. Desa.Donotirto & & & - & 0,00405 & & \\
\hline Jumlah & 160 & & 0,0015 & 0,3606 & & \\
\hline \multicolumn{7}{|l|}{ Kec. Pundong } \\
\hline 1. Desa.Seloharjo & & & 0,016 & 0,019 & 15 & 15,035 \\
\hline 2. Desa. Panjangrejo & & & 0,0012 & - & - & 0,0012 \\
\hline 3. Desa. Srihardono & & & - & - & - & - \\
\hline Jumlah & & & 0,0172 & 0,019 & 15 & 15,0362 \\
\hline \multicolumn{7}{|l|}{ Kec. Srandakan } \\
\hline 1. Desa.Trimurti & - & & - & & & - \\
\hline 2. Desa.Poncosari & 310 & & 0,0016 & & & 310,0016 \\
\hline Jumlah & 310 & & 0,0016 & & & 310,0016 \\
\hline \multicolumn{7}{|l|}{ Kec. Dlingo } \\
\hline 1. Desa. Muntuk & & & 0,0007 & 1,0753 & & 1,076 \\
\hline 2. Desa. Mangunan & & & 0,0007 & - & 10 & 10,0007 \\
\hline 3. Desa. Dlingo & & & 0,0023 & - & - & 0,0023 \\
\hline 4. Desa.Temuwuh & & & 0,003 & - & - & 0,003 \\
\hline 5. Desa.Terong & & & 0,002 & - & 110 & 110,002 \\
\hline 6. Desa Jatimulyo & & & 0,002 & - & - & 0,002 \\
\hline Jumlah & & & 0,0107 & 1,0753 & 120 & 121,086 \\
\hline \multicolumn{7}{|l|}{ Kec. Piyungan } \\
\hline 1. Desa. Srimulyo & & & 0,0005 & 0,009 & 5 & 5,0095 \\
\hline 2. Desa. Srimartani & & & 0,006 & - & - & 0,0006 \\
\hline
\end{tabular}


Etika Khairina, Eko Priyo Purnomo, Ajree Ducol Malawani -- Sustainable Development Goals: Kebijakan Berwawasan Lingkungan Guna Menjaga Ketahanan Lingkungan Di Kabupaten Bantul

Daerah Istimewa Yogyakarta

\begin{tabular}{|c|c|c|c|c|c|c|}
\hline 3. Desa. Sitimulyo & & & - & - & - & - \\
\hline Jumlah & & & 0,0011 & 0,009 & 5 & 126,0981 \\
\hline \multicolumn{7}{|l|}{ Kec. Pandak } \\
\hline 1. Desa. Caturharjo & & & 0,0026 & - & - & 0,0026 \\
\hline 2. Desa.Triharjo & & & 0,0007 & - & - & 0,007 \\
\hline 3. Desa.Wijirejo & & & - & 0,01 & - & 0,01 \\
\hline Jumlah & & & 0,0033 & 0,01 & - & 0,0133 \\
\hline \multicolumn{7}{|l|}{ Kec. Sanden } \\
\hline 1. Desa. Srigading & 150 & & 0,8875 & - & - & 150,8875 \\
\hline 2. Desa. Gadingsari & 120 & & 0,15 & - & - & 120,15 \\
\hline 3. Desa.Gadingharjo & - & & 0,001 & - & - & 0,001 \\
\hline Jumlah & 270 & & 1,0385 & & & 271,0385 \\
\hline \multicolumn{7}{|l|}{ Kec. Pleret } \\
\hline $\begin{array}{l}\text { 1. Desa.. Wonolelo, } \\
\text { Bawuran, Segroyoso }\end{array}$ & - & - & 0,0006 & - & - & 0,0006 \\
\hline 2. Desa.. Pleret & - & - & 0,041 & - & - & 0,041 \\
\hline Jumlah & & & 0,0416 & & & 0,0416 \\
\hline \multicolumn{7}{|l|}{ Kec. Jetis } \\
\hline 1. Desa. Trimulyo & - & - & - & - & - & - \\
\hline 2. Desa. Patalan & - & - & - & - & - & - \\
\hline \multicolumn{7}{|l|}{ Jumlah } \\
\hline Kec. Bantul & - & - & - & - & - & - \\
\hline Kec. Sewon & - & - & - & - & - & - \\
\hline Kec. Banguntapan & - & - & - & - & - & - \\
\hline Kec. Bambanglipuro & - & - & - & - & - & - \\
\hline
\end{tabular}

Sumber: Dinas Kehutanan dan Pertanian Kabupaten Bantul (2009)

Berdasarkan tabel 1 tersebut dapat dilihat bahwa dari 17 kecamatan di Kabupaten Bantul ada 12 kecamatan yang berpotensi untuk dilakukan kawasan lindung, kemudian 5 kecamatan tidak ada area untuk dilakukan kawasan lindung. Kecamatan Srandakan memiliki luas wilayah yang paing luas untuk dilakukan kawasan lindung yaitu seluas 310,0016 Ha yang letaknya di Desa Poncosari, Kecamatan Pleret memiliki luas dan jumlah area yang paling sedikit di antara 17 kecamatan di Kabupaten Bantul seluas 0,0416 Ha.

Data dasar di atas menjadi pedoman dan tolak ukur bagi pemerintah Kabupaten Bantul untuk memilih area atau wilayah yang berpotensi dilakukan kawasan lindung. Data tersebut juga menjadi bukti konkret bahwa pemerintah Kabupaten Bantul telah memikirkan kondisi alam dan keanekaragaman hayati yang ada di Bantul dengan memastikan kondisi pantai, sungai, mata air serta kerawanan longsor dan bencana sehingga keanekaragaman hayati benar-benar dapat dilestarikan sehingga mendukung kehidupan generasi ke depannya.

Kabupaten Bantul juga telah menetapkan langkah-langkah strategis dalam pelestarian keanekaragaman hayati di Kabupaten Bantul, salah satunya adalah kegiatan konservasi, yang dilakukan sebagai salah satu langkah dalam melestarikan keanekaragaman hayati yang berkelanjutan untuk kesejahteraan masyarakat. Pada tahun 2009, Kabupaten Bantul menetapkan flora dan fauna yang dilindungi oleh Kabupaten Bantul (lihat tabel 2).

Berdasarkan data spesies flora dan fauna yang dilindungi, Kabupaten Bantul jelas bahwa berdasarkan status, jumlah spesies 
Tabel 2

Flora Dan Fauna Yang Dilindungi Sejak Tahun 2009

\begin{tabular}{lll}
\hline Golongan & Nama spesies & \multicolumn{1}{c}{ Status } \\
\hline Hewan & Bajing & Terancam \\
menyusui & Tupai & Terancam \\
Burung & Puter & Berlimpah \\
& Jalak & Berlimpah Terancam \\
& Burung hantu & Terancam Berlimpah \\
& Alap-alap & Terancam \\
& Perkutut & Terancam \\
& Kintul & \\
Reptil & Gagak & \\
Ampibi dan & Biawak & Terancam \\
Tumbuh- & Pesut & Terancam Terancam \\
tumbuhan & Ketepeng Kecik & Berlimpah Berlimpah \\
& Gayam & Berlimpah \\
& Jambe & Terancam \\
& Palem Jawa & \\
\hline
\end{tabular}

Sumber: www.dlh.bantulkab.go.id diunduh 4 april 2020

hewan dan tumbuhan yang terancam daripada yang melimpah memberi pemahaman bahwa pembangunan sejauh ini belum melihat dan memikirkan lingkungan karena banyaknya spesies yang terancam ekosistem. Oleh karena itu perlu diambil langkah-langkah khusus oleh pemerintah untuk tetap melindungi ekosistem dari flora dan fauna demi kelestarian flora dan fauna dan generasi mendatang dengan menetapkan jenis hewan yang dilindungi agar dapat di lestarikan kembali.

Memastikan keberlanjutan semua spesies dan kelangsungan hidup komunitas biologis, serta mempertahankan fungsi ekosistem sangat penting dalam pengelolaan keanekaragaman hayati dan ekosistem. Manusia sebagai bagian dari ekosistem, maka penilaiannya akan mempengaruhi tujuan pengelolaan ekosistem. Oleh karena itu, perlu untuk mengembangkan pemahaman bersama bahwa mengelola sumberdaya secara berkelanjutan akan memberikan manfaat jangka panjang bagi generasi mendatang.
Pengelolaan Keanekaragaman Hayati Untuk Mendukung Ketahanan Lingkungan dan Pembangunan Berkelanjutan Di Kabupaten Bantul

Mengatasi permasalahan pembangunan dan hubungannya terhadap lingkungan dapat diupayakan dengan pengelolaan secara bertahap yang dilakukan dengan membudayakan masyarakat dan kekuatan ekonomi. Di samping itu, memberikan kewenangan sehingga ada tanggung jawab khusus dalam pengelolaan lingkungan juga dapat dipahami sebagai tahapan melestarikan lingkungan. Pembangunan berkelanjutan (SDG's) adalah pembangunan yang tidak akan pernah berhenti, tingkat kehidupan generasi masa depan harus lebih baik dan tidak memburuk dari tingkat pengalaman saat ini, dalam arti bahwa generasi saat ini dapat menggunakan berbagai pendekatan atau strategi dalam penggunaannya namun tidak melampaui pemanfaatannya sehingga mempertahankan eksistensinya, sementara generasi mendatang meskipun dihadapkan pada ketersediaan sumberdaya alam yang terbatas namun generasi penerus tersebut harus mampu memanfaatkan teknologi dan pengetahuan sehingga dapat mempertahankan ketersediaannya dan sadar bahaya dari kegiatan eksploitasi sumberdaya alam. Kegiatan pengembangan tersebut diupayakan agar generasi mendatang sejahtera dan dapat bertahan hidup serta berdampingan dengan alam dan dikatakan berkelanjutan jika tidak ada masalah ketimpangan antar generasi.

Keanekaragaman hayati adalah aset untuk pembangunan regional dan nasional, sehingga manajemen harus dipastikan terintegrasi antar sektor. Keseriusan pemerintah Kabupaten Bantul dalam mengelola keanekaragaman hayati telah lama diterapkan. Hal tersebut dapat dilihat 
Etika Khairina, Eko Priyo Purnomo, Ajree Ducol Malawani -- Sustainable Development Goals: Kebijakan Berwawasan Lingkungan Guna Menjaga Ketahanan Lingkungan Di Kabupaten Bantul

Daerah Istimewa Yogyakarta

dari penciptaan peraturan daerah Kabupaten Bantul tentang kebijakan pengelolaan keanekaragaman hayati. Berdasarkan Peraturan Daerah Kabupaten Bantul No 12 Tahun 2015 Tentang Perlindungan dan pengelolaan Lingkungan hidup Pasal 12 bahwa pemerintah dapat bermitra dengan kelompok masyarakat, organisasi lingkungan hidup dan asosiasi dalam pengelolaan lingkungan hidup, pemerintah daerah lainnya baik dengan pemerintahan kota di DIY ataupun luar DIY.

Sumberdaya alam hayati dan ekosistem memiliki posisi penting dalam kehidupan manusia, seperti yang disebutkan sebelumnya bawa berkurangnya habitat dan rusaknya lingkungan erat hubungannya dengan pemanfaatan keanekaragaman hayati. Pemanfaatan sebenarnya menunjang kesejahteraan masyarakat, sehingga dapat mendukung pertumbuhan ekonomi daerah.

Pemanfaatan perlu diatur lebih lanjut untuk dikelola dan dimanfaatkan, sebab pemanfaatan tersebut harus dapat mendorong kea rah pelestarian keanekaragaman hayati. Sumberdaya alam hayati dalam bentuk hewan yang hidup di darat, air dan udara perlu memikirkan pelestariannya untuk menghindari tindakan yang merusak lingkungan dan pemanfaatan berlebihan, yang menyebabkan kepunahan. Secara lebih rinci pengelolaan keanekaragaman hayati di Kabupaten Bantul diuraikan sebagai berikut.

(1). Konservasi Burung dan Ikan. DLH Kabupaten Bantul telah mengatur pelestarian burung dan hewan ikan pada 12 Mei 2016, Perlindungan diatur dalam Peraturan Bupati Nomor 24 tahun 2016 tentang Konservasi Burung dan Ikan. Alasan penerbitan peraturan dalam upaya melestarikan burung dan ikan terkait dengan kegiatan berburu, pembibitan dan pemanfaatan yang dilakukan oleh semua orang.
Konservasi berusaha keras demi kelangsungan hidup burung dan ikan melawan bisnis yang mengancam kehidupan mereka. Selain pelestarian sebagai hewan di daerah Bantul, peraturan tentang konservasi burung dan ikan juga bertujuan untuk menghindari bahaya kepunahan, melindungi kemurnian genetik dan keanekaragaman spesies hewan, menjaga keseimbangan ekosistem. Berdasarkan peraturan, faktor-faktor yang dapat mengancam kelestarian ekosistem adalah perubahan dan perubahan penggunaan lahan, penggunaan sumberdaya alam yang tidak ramah lingkungan seperti kegiatan penambangan, penebangan, dan perburuan hewan, pencemaran lingkungan akibat aktivitas manusia, dan perubahan iklim.

(2). Konservasi Penyu di Wilayah Pesisir Bantul. Pada tahun 2014 Kabupaten Bantul bersama dengan Departemen Kelautan dan Perikanan membentuk konservasi penyu di wilayah pesisir Bantul, untuk melaksanakan pengelolaan terhadap penyu berpusat pada organisasi masyarakat. Jenis penyu di antaranya termasuk penyu belimbing, penyu tempayan, penyu hijau, penyu sisik, penyu abu, penyu datar, dan penyu datar. Penyupenyu tersebut tersebar di beberapa garis pantai di Kabupaten Bantul yaitu daerah Pantai Baru, Pantai Gua Pinus, dan Pantai Pelangi mengikuti Keputusan Bupati Bantul pada tahun 2014 tentang Reservasi Kawasan Konservasi Taman Pesisir.

Tujuan konservasi penyu tersebut adalah untuk melestarikan hewan yang hidup di darat dan di laut pesisir Kabupaten Bantul. Berdasarkan penjelasan Iswanto sebagai perwakilan dari Dinas Kelautan dan Perikanan dan organisasi masyarakat sebagai pengelola tahap awal yang dilakukan Pemerintah Daerah yang dibantu masyarakat juga berperan sebagai kelompok pemerhati penyu bagai 
pengelola konservasi penyu dilakukan dengan penemuan telur penyu biasanya mulai bulan Mei hingga September, masyarakat akan menyelamatkan penyu bertelur dan akan dilakukan pemeliharaan setelah telur penyu ditetaskan dan ditemukan tukik (anak penyu), maka selama tiga hari setelah menetas tukik akan dilepas ke laut untuk bisa hidup bebas hingga tumbuh besar dan kembali ke permukaan untuk bertelur lagi.

Dari empat pantai, konservasi paling melimpah adalah di Pantai Pelangi dengan 14 sarang masing-masing 60-70 telur (Istiwanto). Pengelolaan konservasi juga diarahkan sebagai pemberdayaan masyarakat pesisir di Kabupaten Bantul. Untuk terus melestarikan konservasi penyu di pantai Bantul, masyarakat perlu memiliki kesadaran untuk melindungi pantai dan memberikan pemahaman tentang bagaimana menanganinya ketika telur penyu ditemukan.
Mengingat kondisi alam secara signifikan mempengaruhi konservasi. Seperti yang disampaikan saat monev oleh Agung Budiantoro petugas yang melakukan pemantauan dan evaluasi (Monev), keadaan daerah pantai yang bersih akan mempengaruhi penyu yang akan mendarat, sehingga masyarakat sebagai mitra pemerintah dalam melakukan konservasi diharapkan mampu melindungi lingkungan dan mencegah penyu dari kepunahan sebagaimana dimaksud oleh pemerintah Kabupaten Bantul dan Dinas Kelautan dan Perikanan.

Pada tahun 2013 dan 2014, pemerintah Kabupaten Bantul dan Kantor Kelautan dan Perikanan (DKP) berfokus pada pembangunan dan pelatihan masyarakat untuk konservasi. Kegiatan konservasi yang dinyatakan dilakukan untuk menjaga perlindungan hal tersebut dapat dilihat pada tabel 3 .

Tabel 3

Program Konservasi Lingkungan Pada Tahun 2013-2014 Di Kabupaten Bantul

\begin{tabular}{ll}
\hline \multicolumn{1}{c}{ Tahun $\mathbf{2 0 1 3}$} & \multicolumn{1}{c}{ Tahun 2014} \\
\hline Pembangunan gedung penyedia data dan informasi & Pelatihan meningkatkan sumber daya manusia di bidang \\
yang dikenal dengan Gedung Pusdatin, gedung tersebut & Pelayanan Prima. Hal tersebut bertujuan agar masyarakat \\
ialah fasilitas pendukung dan juga pusat informasi & dapat berinteraksi dengan baik dengan wisatawan. \\
tentang konservasi penyu di kawasan tersebut & \\
Pembangunan fasilitas umum seperti toilet untuk & Sosialisasi tentang kawasan konservasi untuk mentransfer \\
mendukung kawasan konservasi harus direproduksi & pengetahuan tentang konservasi hewan yang terancam \\
lagi & punah. \\
Pengadaan papan informasi sebagai operasional & Pelatihan menjadi pemandu wisata untuk daerah masing- \\
yang akan digunakan sebagai pusat informasi jadwal & masing. Yang direkrut dari anggota Pokdarwis dan \\
penutupan area pada jam-jam tertentu ketika penyu & Kelompok Konservasi Penyu harus dipandu oleh \\
mendarat, plang yang berfungsi sebagai situs pendidikan & masyarakat itu sendiri. \\
untuk kura-kura, dan sebagainya. & \\
Publikasi tentang kawasan konservasi penyu, baik & Pemanfaatan terumbu karang menjadi nilai ekonomis yang \\
melalui web, pamflet, atau media lainnya & dilaksanakan dengan Pelatihan membuat terumbu karang \\
meningkatkan sumberdaya manusia yang berkualitas & Mendukung situs ekowisata di Pantai Goa dengan \\
untuk pemasaran pariwisata konservasi penyu yang & pembuatan database konservasi penyu. \\
di ikuti dengan langkah Pelatihan untuk pemandu & Pengumpulan databiologis dan ekologis tentang pendaratan \\
wisata yang merupakan anggota Pokdarwis (Kelompok & penyu di Pantai Bantul. \\
Kesadaran Pariwisata). & \\
Memberikan Tagging Microchip Reader untuk & Pemberitahuan berupa Sosialisasi zonasi kawasan \\
kelompok konservasi penyu Mino Raharjo di Pantai & konservasi penyu sebagai Daerah Reservasi Taman Pesisir. \\
Goa Cemara, Patihan. & \\
\hline
\end{tabular}
sumber: www.uad.ac.id diunduh 10 April 2020 
Etika Khairina, Eko Priyo Purnomo, Ajree Ducol Malawani -- Sustainable Development Goals: Kebijakan Berwawasan Lingkungan Guna Menjaga Ketahanan Lingkungan Di Kabupaten Bantul

Daerah Istimewa Yogyakarta

Salah satu tujuan program yang dilaksankan tersebut ialah untuk membantu perekonomian masyarakat setempat. Pada saat pelepasan anak penyu ke lautan maka penyu yang tersebar di pantai akan menjadi tempat yang diminati dan dinantikan oleh masyarakat baik lokal maupun luar daerah sehingga masyarakat setempat dapat memanfaatkan kesempatan tersebut.

(3) Taman Pesisir Kabupaten Bantul. Wilayah pesisir Kabupaten Bantul yang terletak di Desa Tirtohargo, Kretek, Bantul, memiliki sumberdaya hayati yang menarik, potensi potensi sumberdaya alam berupa penyu dan vegetasi mangrove. Area Konservasi Taman Pesisir terdiri dari darat dan laut, yaitu Area Konservasi Penyu, yang meliputi area seluas 50 hektar dan Area Konservasi Mangrove Baros, seluas 132 hektar. Pengelolaan dilakukan oleh Dinas Kelautan dan Perikanan Kabupaten Bantul. Kawasan Baros Mangrove adalah upaya sadar konservasi dari pemerintah Kabupaten Bantul dan masyarakat untuk menyelamatkan wilayah pantai selatan (Pantai Baros) dari abrasi pantai dan menyelamatkan lahan pertanian di sekitar pantai, mengingat bahwa air yang mengandung garam sering meresap ke pertanian tanah.

Berdasarkan Keputusan Bupati Kabupaten Bantul Nomor 284 Tahun 2014 Tentang Pembagian Area Konservasi diupayakan sebagai usaha melindungi dan melestarikan keanekaragaman hayati ekosistem mangrove Baros, sebagaimana ditunjukkan pada gambar 1 .

Untuk itu, berdasarkan peraturan tersebut area konservasi dibagi menjadi tiga area, yaitu: area inti (10 hektar), zona rehabilitasi (94 hektar), dan area penggunaan terbatas (28 hektar).

Rincian area yang dicairkan tercantum dalam Peraturan Menteri Kelautan dan Perikanan Republik Indonesia Nomor 17/MEN/2008, adalah (a). Area inti, ditetapkan sebagai daerah pemijahan, tempat bersarang, tempat pembibitan,

Peta Zona Konservasi Pesisir Mangrove Kabupaten Bantul

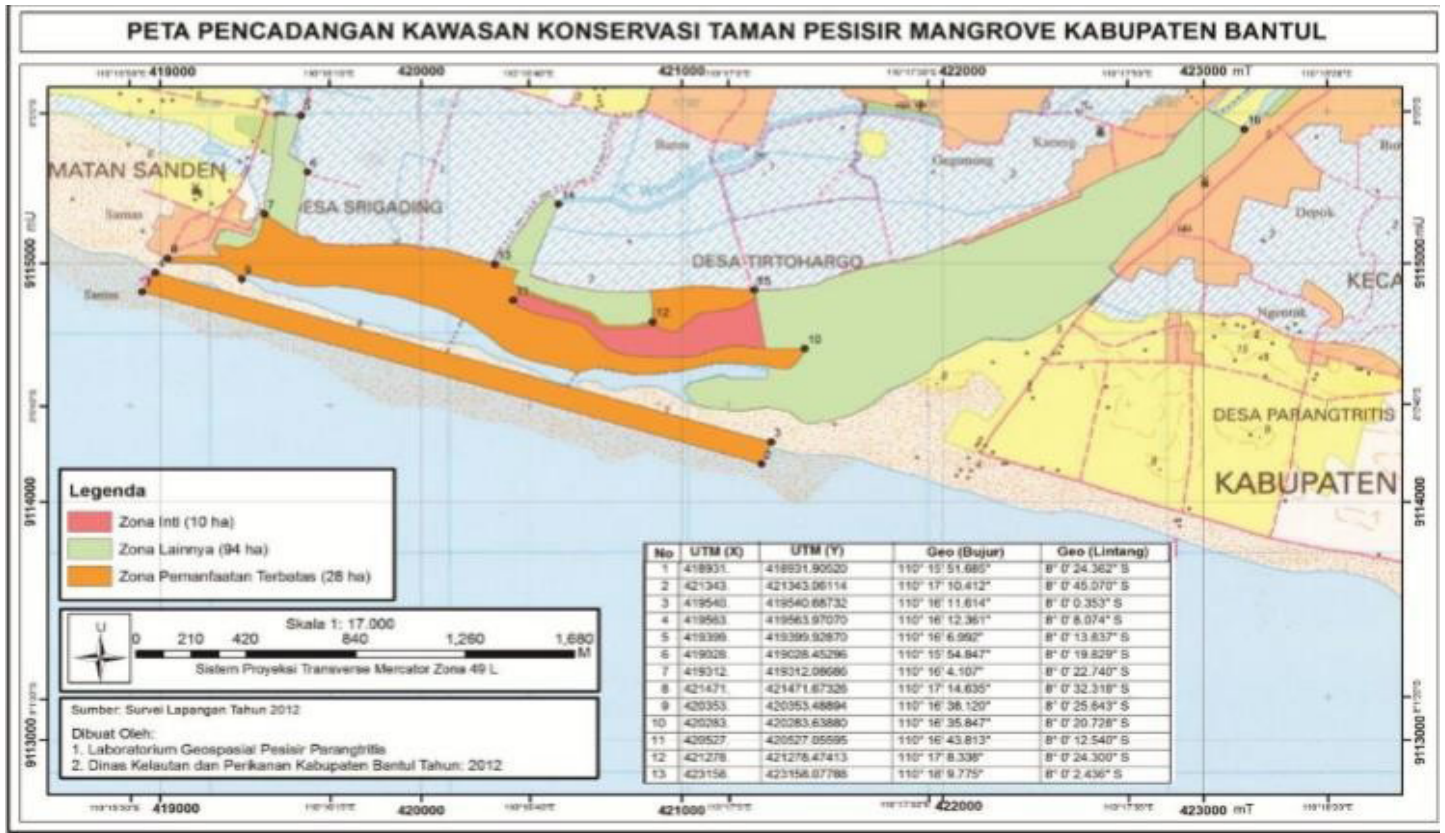

Sumber: Peraturan Bupati Bantul Nomor 284 Tahun 2014 
tempat mencari makan ikan dan biota perairan lainnya serta ekosistem pesisir dan pulau-pulau kecil yang rentan terhadap perubahan. (b). Area penggunaan terbatas, yang merupakan habitat bagi habitat ikan dan perlindungan populasi, pariwisata dan penelitian rekreasi dan pendidikan. (c). Area pemulihan (rehabilitasi) zona ini berada di luar zona inti dan pemanfaatan terbatas, karena fungsi dan kondisinya diartikan sebagai zona tertentu. Rincian area tersebut ditunjukkan pada gambar 2 .

Pemeliharaan Kawasan Hutan Mangrove Baros sebagai Kawasan Konservasi Taman Pantai Kabupaten Bantul dilakukan melalui upaya konservasi, pencadangan serta pelestarian fungsi, yang kemudian dapat dimanfaatkan dan memperkuat ekonomi masyarakat, oleh karena itu perlu dilindungi dan dikelola secara serius mengingat ada fungsi dan manfaat fisik, biologis, dan ekonomi yang dapat meningkatkan kesejahteraan dari masyarakat, terutama masyarakat di sekitar daerah tersebut.
Mengoptimalkan kawasan konservasi taman pesisir maka 18 Februari di Balai Desa Tirtohargo Kecamatan Kretek, dibentuklah suatu lembaga yang tugasnya melaksanakan pengelolaan konservasi mangrove Baros tersebut yang diikuti 40 orang peserta dari masyarakat sekitar taman pesisir dan aparat desa. Pengelolaan kawasan konservasi dilakukan dengan penanaman dan pemeliharaan mangrove serta penebaran dan pemeliharaan kerang dan kepiting Bakau.

(4). Kebun Buah Nawungan. Kebun Buah Nawungan merupakan salah satu objek wisata alam yang berlokasi di Dusun Nawungan, Desa Mangunan, Kecamatan Dlingo, Kabupaten Bantul, yang terletak di Perbukitan Mangir dengan ketinggian antara 150-400 meter dan luas 24 hektar. Awalnya lahan kebun Nawungan ialah lahan kritis, terdapat beberapa permasalahan lingkungan yang disebabkan oleh pemanfaatan lahan untuk pertanian dan pemukiman warga dengan mengabaikan prinsip pengelolaan lahan

Gambar 2

Peta Zona Konservasi Taman Penyu Pantai Kabupaten Bantul

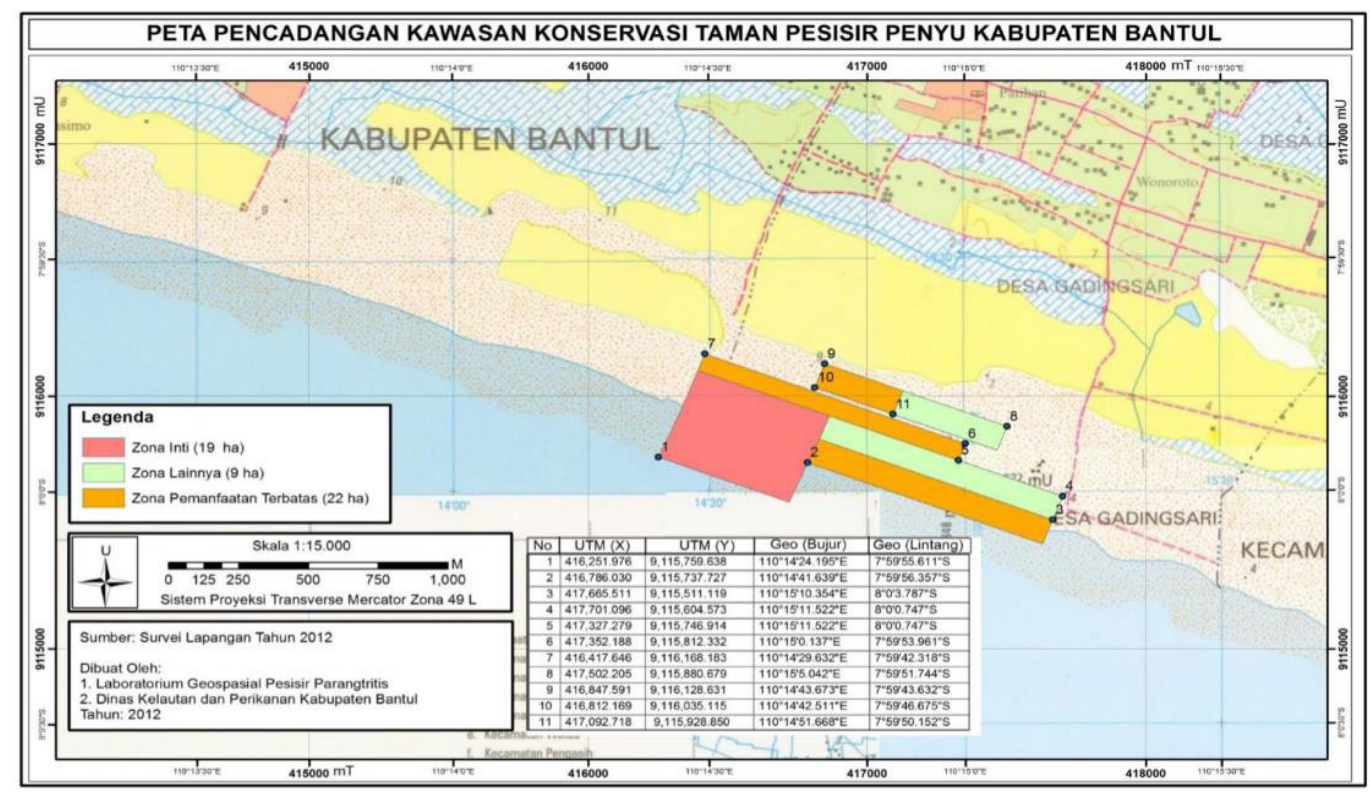

Sumber: Peraturan Bupati Bantul Nomor 284 Tahun 2014 
Etika Khairina, Eko Priyo Purnomo, Ajree Ducol Malawani -- Sustainable Development Goals: Kebijakan Berwawasan Lingkungan Guna Menjaga Ketahanan Lingkungan Di Kabupaten Bantul

Daerah Istimewa Yogyakarta

kritis dan sumberdaya air untuk kehidupan ke depannya yang lebih baik. Kemudian sejak tahun 2014 program pemanfaatan lahan tersebut mulai dimanfaatkan menjadi agrowisata untuk lahan pertanian produktif (lihat gambar 3).

Pendirian Kawasan Kebun Buah Nawungan merupakan langkah untuk melestarikan alam dan menjaga lingkungan serta membudidayakan tanaman dan membantu memenuhi kebutuhan buah secara nasional khususnya Kabupaten Bantul. Kawasan Kebun Buah Nawungan yang berpotensi menjadi agrowisata dikelola langsung oleh masyarakat sebagai komunitas petani buah yang potensial kemudian dijadikan tempat wisata yang bersifat edukatif.

Pemerintah Kabupaten Bantul Badan Perencanaan dan Pembangunan Daerah (Bappeda) telah menyusun dari konsep pengembangan dan konsep perencanaan. Salah satu tujuan pengembangan dan perencanan Kebun Buah Nawungan ialah tetap menjaga tersedianya sumberdaya air, distribusi air bersih dan drainasi. Hal tersebut diupayakan agar tidak terjadi dampak negatif dari pengembangan kebun buah tersebut. Skema Sumberdaya Air yang dirancang sebagai Masterplan Kebun Buah Nawungan ditunjukkan pada gambar 4 .

Berdasarkan gambar 3 dan 4 tersebut jelas bahwa pembangunan berwawasan lingkungan telah diterapkan oleh pemerintah Kabupaten Bantul serta telah menjaga kualitas lingkungan hidup. Gambar 4 Skema Sumberdaya air disediakan untuk tiga area yang terbagi untuk wisatawan dan dua bagian khusus wilayah pertanian. Di samping itu sistem drainasi juga perlu dipertimbangkan dan tidak mementingkan kehidupan manusia semata, pembangunan tidak boleh mengabaikan lingkungan dan menghindari kerusakan alam mengingat aktivitas pembangunan dapat memicu pengaruh yang cukup besar kepada lingkungan baik yang sifatnya alamiah dan fisik, sehingga pembangunan dan lingkungan tetap seimbang.

Memperhatikan kondisi fisik dan keadaan lingkungan hidup sekitar yang berhubungan dengan kehidupan sekarang dan mendatang maka menjaga kualitas

Gambar 3

Kawasan Kebun Buah Nawungan Di Kabupaten Bantul

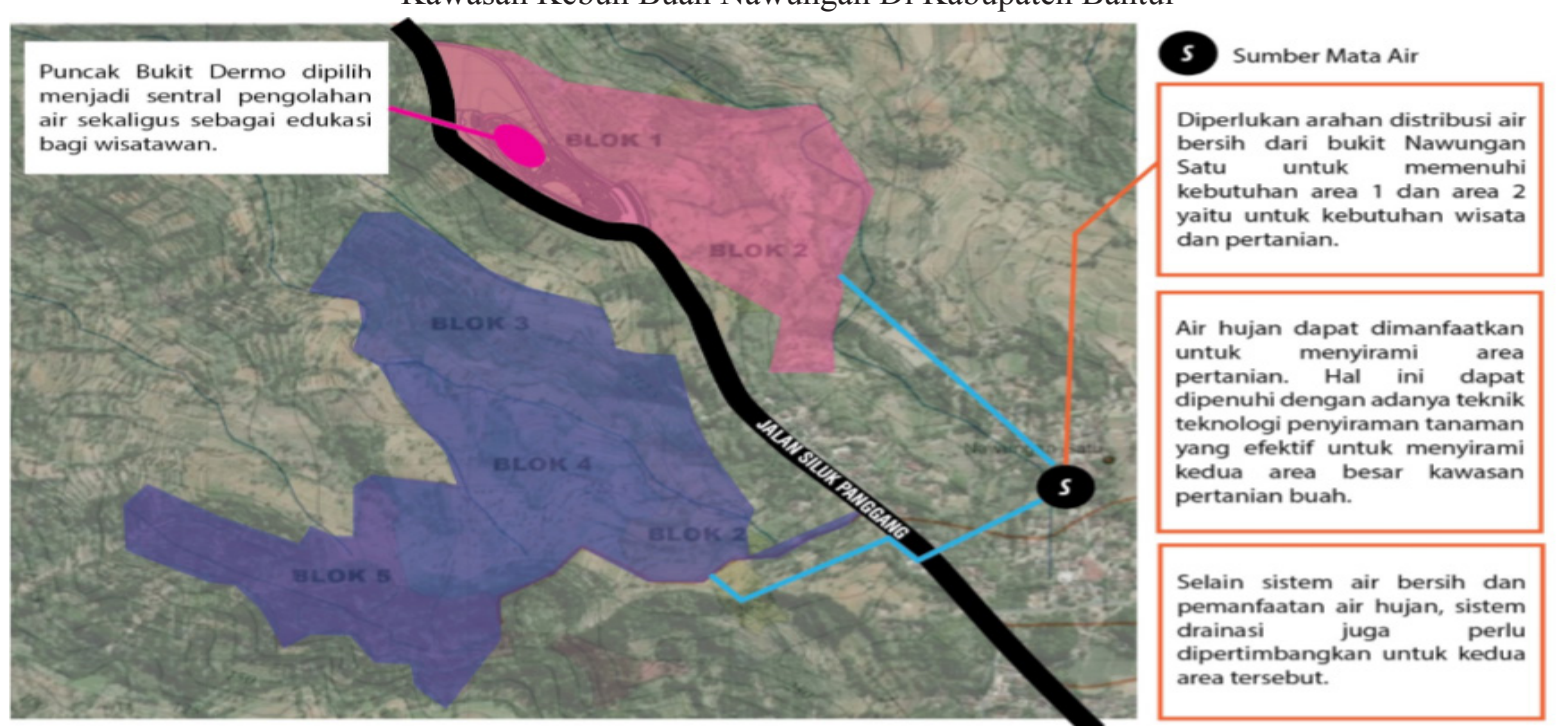

Sumber: www.bappeda.bantulkab.go.id, diunduh 25 mei 2020 


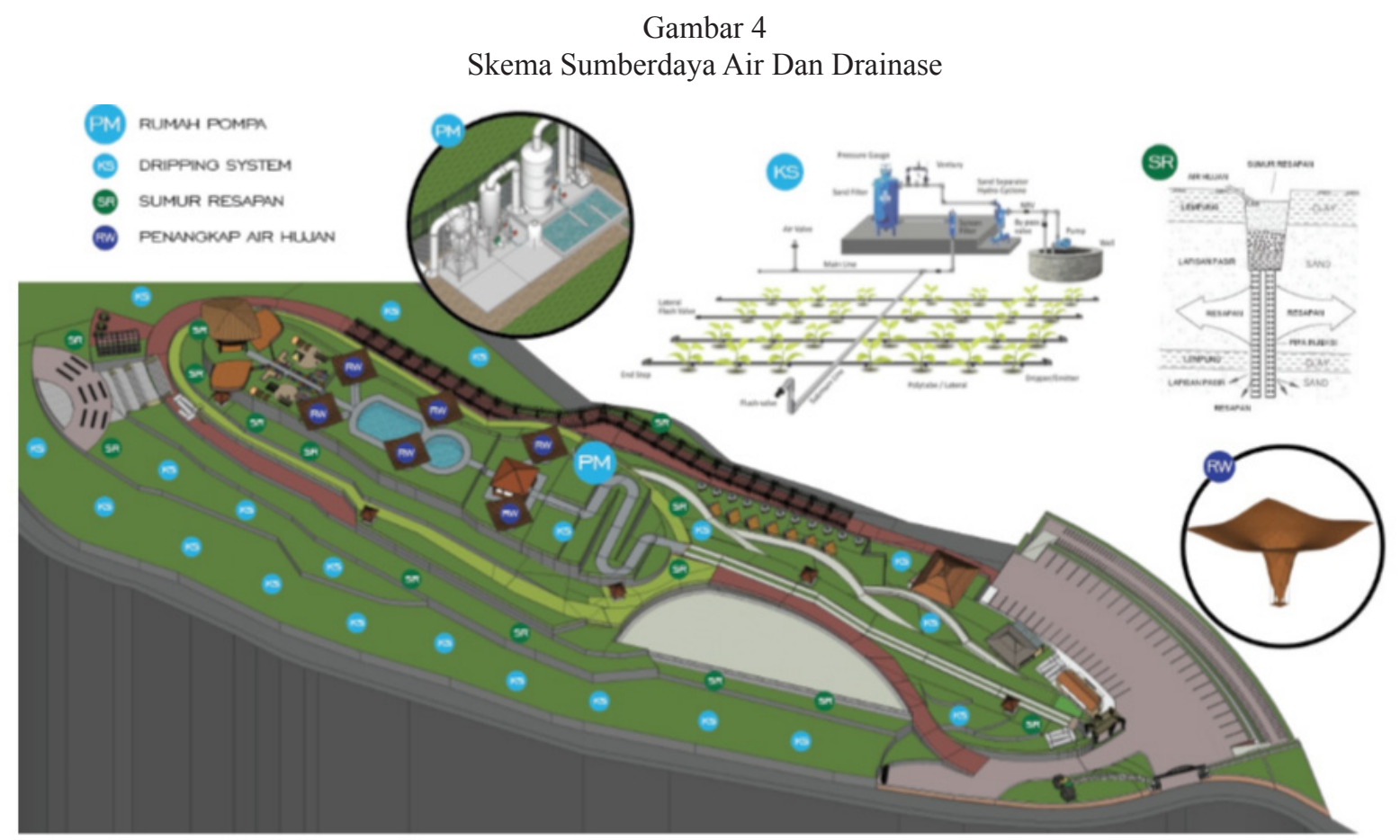

Sumber: www.bappeda.bantulkab.go.id, diunduh 25 mei 2020

lingkungan hidup ialah suatu keharusan. Menjaga kualitas lingkungan dapat ditentukan dari terpenuhinya kebutuhan hidup demi kelangsungan hidup hayati, manusiawi, dan terpenuhinya kebebasan untuk memilih. Pada hakikatnya kehidupan manusia di bumi sangat bergantung pada alam dan lingkungan, kebutuhan pokok, seperti oksigen, pangan, sandang dan papan, obat-abatan bersumber dari alam, maka manusia mempunyai kewajiban untuk menjaga ketahanan lingkungan dan mempertahankan kehidupan hayati, di samping dapat dimanfaatkan untuk generasi mendatang kehidupan hayati juga akan berdampak positif untuk bumi. Oleh karena itu lingkungan penting dipelihara agar dapat mendukung tingkat hidup masyarakat.

Sumberdaya alam sebagai pendukung keberlangsungan hidup dihasilkan dari kemampuan manusia berinteraksi dengan lingkungan. Manusia dan lingkungan selalu hidup berdampingan maka keseimbangan antara keduanya harus diupayakan agar dapat seimbang. Keseimbangan tersebutlah yang sedang diupayakan oleh pemerintah Kabupaten Bantul, mengingat Kabupaten Bantul memiliki mempunyai daya tarik sumberdaya alam hayati, potensi alam hayati yang tinggi termasuk di dalamnya flora dan fauna berupa satwa penyu dan ekosistem mangrove. Potensi yang terkandung dapat dimanfaatkan dalam bidang pendidikan, untuk menambahkan kesadaran serta meningkatkan keinginan untuk melestariakan alam.

\section{SIMPULAN}

Berdasar penjelasan tersebut di atas dapat ditarik simpulan sebagai berikut.

Pertama, Kabupaten Bantul Daerah Istimewa Yogyakarta, merupakan salah satu daerah yang memiliki keanekaragaman hayati, yang jika tidak dikelola dengan baik kekayaannya dapat semakin berkurang, habis dan punah. Pengelolaan keanekaragaman 
Etika Khairina, Eko Priyo Purnomo, Ajree Ducol Malawani -- Sustainable Development Goals: Kebijakan Berwawasan Lingkungan Guna Menjaga Ketahanan Lingkungan Di Kabupaten Bantul

Daerah Istimewa Yogyakarta

hayati dimaksudkan untuk memberdayakan kehidupan masyarakat untuk dapat memanfaatkan sumberdaya secara optimal dan juga meningkatkan kesejahteraan hidup masyarakat.

Kedua, keberadaan manusia memberi tekanan pada bumi yang dibuktikan dengan semakin tingginya tingkat kerusakan bumi. Jasa ekosistem sangat penting untuk kelangsungan hidup dan kesejahteraan manusia, oleh karena itu dengan persetujuan $\mathrm{PBB}$ untuk melindungi keanekaragaman hayati dan jasa ekosistem adalah salah satu tujuan yang harus dicapai sebagai berkelanjutan pembangunan, dalam hal ini keberlanjutan pembangunan untuk ketahanan lingkungan.

Ketiga, menjaga keanekaragaman hayati dalam rangka menghindari kepunahan dan penggunaan berlebihan dari beberapa pihak, peran pemerintah diperlukan dalam pengelolaannya. Pengelolaan keanekaragaman hayati yang dilakukan oleh pemerintah Kabupaten Bantul seperti konservasi burung dan ikan, konservasi penyu di beberapa pantai dan pengelolaan konservasi ekosistem mangrove adalah kebijakan yang dikeluarkan untuk melindungi hewan dari kepunahan dan dapat digunakan secara ekonomi dalam mendukung ekonomi masyarakat dan memberdayakan masyarakat sehingga masih bisa diwariskan oleh generasi mendatang. Dalam konteks pembangunan berkelanjutan, pengelolaan keanekaragaman hayati perlu dikelola dengan melihat betapa pentingnya sumberdaya, atau keanekaragaman hayati, untuk kelangsungan hidup manusia.

Keempat, Kabupaten Bantul telah menerapkan konsep pembangunan berkelanjutan dengan mengeluarkan beberapa kebijakan atau program terhadap manajemen dalam arti bahwa Kabupaten Bantul telah menerapkan kebijakan yang berwawasan lingkungan dalam konsep pembangunan berkelanjutan dengan tujuan jangka panjang untuk keberlangsungan makhluk hidup dan menjaga ketahanan lingkungan. Kemampuan mengeksplorasi sumberdaya alam dengan membatasi atau memberikan kontrol pada setiap kegiatan dalam pemanfaatan sumber alam dan mempertimbangkan kehidupan yang berkelanjutan dalam pemanfaatannya, semua tindakan tersebut merupakan bagian dari usaha menjaga ketahanan lingkungan.

Kelima, upaya yang dapat dilakukan dakam mengatasi masalah pada lingkungan hidup, yaitu (1). Menggunakan teknologi yang peduli lingkungan dalam pengelolaan sumberdaya termasuk yang dapat diperbaharui dan yang tidak dapat diperbaharui dengan memperhatikan daya dukung dan daya tampungnya. (2). Salah satu peran pemerintah ialah menetapkan regulasi yang dapatmembatasi kegiatan merugikan lingkungan, maka dibutuhkan peraturan yang adil dan konsisten. termasuk untuk menghindari terjadinya pencemaran lingkungan dan kerusakan sumberdaya alam. (3). Memberdayakan masyarakat dengan mendukung peningkatan kekuatan ekonomi setempat secara bertahap guna menjaga ketahanan lingkungan. (4). Melibatkan dan menyertakan peran masyarakat sebagai aktor yang terlibat langsung dalam pemanfaatan alam. (5). Indikator keberhasilan pengelolaan sumberdaya alam guna mencapai ketahanan lingkungan harus diterapkan dan dievaluasi sebagai perbaikan mencapai keberhasilan dalam pengelolaan. (6). Menjaga dan mencintai lingkungan seperti memelihara keragaman konservasi yang sedang diterapkan kemudian penetapan konservasi yang baru tanpa mengabaikan konservasi yang lebih dulu ada. 


\section{DAFTAR PUSTAKA}

Ali, M., C.M.Kennedy, J. Kiesecker, dan Y. Geng, 2018, Integrating biodiversity offsets within Circular Economy policy in China. Journal of Cleaner Production, No. 185, hh.32-43.

Andrianandrasana, H. T., 2016, Testing the effectiveness of community-based conservation in conserving biodiversity, protecting ecosystem services, and improving human well-being in Madagascar.

Anggraini, W., 2018, Keanekaragaman Hayati Dalam Menunjang Perekonomian Masyarakat Kabupaten Oku Timur, Vol. 16, No. 2, hh. 99-106.

Ardiyansari, N., Dkk., 2019, Peran Organisasi Pemuda Dalam Pengembangan Ekowisata Kawasan Mangrove Guna Mewujudkan Ketahanan Lingkungan (Studi pada Keluarga Pemuda Pemudi Baros (KP2B) Di Dusun Baros, Desa Tirtohargo, Kecamatan Kretek, Kabupaten Bantul, Daerah Istimewa Yogyakarta). <https://doi.org/10.22146/ jkn.46194> Vol. 25, No. 2, hh. 226-252. Arianti, D., dan L. Satlita, 2018,. Collaborative Governance Dalam Pengembangan Konservasi Mangrove Baros di Desa Tirtohargo Kecamatan Kretek Kabupaten Bantul. Jurnal Adinegara, Vol. 7, No. 6, hh. 809-827.

Arlis, S., Muhammadi, dan Chandra, 2018, Konservasi Hutan Mangrove Dan Pengembangan Ekowisata Kampung Mangrove Di Medan Labuhan Dan Bagan Serdang. No. 6, hh. 77-81.

Budianto, 2008, Pelaksanaan Sistem Kebijaksanaan Pengelolaan Lingkungan Hidup dengan Pengelolaan
Pembangunan Berkelanjutan dan Berwawasan Lingkungan. h. xii.

Candra, S., W. Sari, dan D. Wahidin, 2020, Penguatan Kewarganegaraan Ekologis Untuk Mewujudkan Ketahanan Lingkungan (Studi di Kampung Gambiran, Kelurahan Pandeyan, Kecamatan. Jurnal Ketahanan Nasional, Vol. 26, No. 1, hh. 87-107.

Dewi Sanjaya, I., dan S. Martono, 2012, Management Analysis Journal. Vol. 1, No. 2, hh.120-128.

Diz, D., D.Johnson, M. Riddell, S. Rees, J. Battle, K.Gjerde, K., dan J.M. Roberts, 2018, Mainstreaming marine biodiversity into the SDGs: The role of other effective area-based conservation measures (SDG 14.5). Marine Policy, No. 93(August 2017), hh. 251-261.

Drakel, A., 2010, Kebijakan pengelolaan lingkungan hidup berbasis ekonomi sumberdaya di Propinsi Maluku Utara. Agrikan: Jurnal Ilmiah Agribisnis Dan Perikanan, Vol. 3, No. 1, h. 90.

Eastwood, A., R. Brooker, R.J. Irvine, R.R.E. Artz, L.R.Norton, J.M. Bullock, R.J. Pakeman, 2016, Does nature conservation enhance ecosystem services delivery? Ecosystem Services, Vol. 17, hh. 152-162.

Fatimah, S. S., 2018, Peran Pemerintah Mengelola Sumber Daya Hutan Dalam Rangka. (May).

Ferrier, S., K.N.Ninan, P. Leadley, R. Alkemade, L.A. Acosta, H.R. Akçakaya, B. Wintle, eds., 2019, Summary for policymakers of the methodological assessment of scenarios and models of biodiversity and ecosystem services of the Intergovernmental Science- 
Etika Khairina, Eko Priyo Purnomo, Ajree Ducol Malawani -- Sustainable Development Goals: Kebijakan Berwawasan Lingkungan Guna Menjaga Ketahanan Lingkungan Di Kabupaten Bantul

Daerah Istimewa Yogyakarta

Policy Platform on Biodiversity and Ecosystem Services. Secretariat of the Intergovernmental Science-Policy Platform on Biodiversity and Ecosystem Services, (May 2019), h. 39.

Fukuda-Parr, S., 2016, From the Millennium Development Goals to the Sustainable Development Goals: shifts in purpose, concept, and politics of global goal setting for development. Gender and Development, Vol. 24, No. 1, hh. 43-52. García-Llorente, M., P.A.Harrison, P. Berry, I. Palomo, E. Gómez-Baggethun, I. Iniesta-Arandia, B. Martín-López, 2018, What can conservation strategies learn from the ecosystem services approach? Insights from ecosystem assessments in two Spanish protected areas. Biodiversity and Conservation, Vol. 27, No. 7, hh. 1575-1597.

García Márquez, J. R., T.Krueger, C.A. Páez, C.A. Ruiz-Agudelo, P. Bejarano, T. Muto, dan F. Arjona, 2017, Effectiveness of conservation areas for protecting biodiversity and ecosystem services: a multi-criteria approach. International Journal of Biodiversity Science, Ecosystem Services and Management, Vol. 13, No. 1, hh. 1-13.

Gordon, J. E., R. Crofts, dan E. Díaz-Martínez, 2017, Geoheritage conservation and environmental policies: Retrospect and prospect. Geoheritage: Assessment, Protection, and Management, hh. 213-235.

Gull, S., MA, A., A.M. Dar, T.B. Kifle, J. Stewart, M. Bennett, C. Worte, 2017, Mountain Watersheds and Ecosystem Services : Balancing multiple demands of forest management in ... Mountain Watersheds and Ecosystem Services :
Balancing. International Journal of Water Resources Development, Vol. 33, No. 3, hh. 1-9.

Hák, T., S.Janoušková, dan B. Moldan, 2016, Sustainable Development Goals: A need for relevant indicators. Ecological Indicators, Vol. 60, hh. 565-573.

Hardiyanti, M., dan A.Aminah, 2019, Tinjauan Yuridis Terhadap Prinsip Pemberdayaan Masyarakat Dan Pembangunan Berkelanjutan Dalam Pengelolaan Sumber Daya Hutan Di Pulau Jawa. Bina Hukum Lingkungan, Vol. 4, No. 1, h. 135.

Huda, N., 2008, Strategi Kebijakan Pengelolaan Mangrove Berkelanjutan Di Wilayah Pesisir Kabupaten Tanjung Jabung Timur, Jambi, Tesis, Universitas Diponegoro Semarang.

Isbell, F., A.Gonzalez, M. Loreau, J. Cowles, S. Díaz, A. Hector, A. Larigauderie, 2017, Linking the influence and dependence of people on biodiversity across scales. Nature, 546(7656), hh. 65-72.

Junyuan, Dahl Olli, D. Bondeson, A.P. Mathew, K. Oksman, F.V. Ferreira, J. Uribe-Calderon, 2019, United Nations Sustainable Development Cooperation Framework. Carbohydrate Polymers, Vol. 6, No. 1, hh. 5-10.

Keenan, R. J., G.Pozza, dan J.A. Fitzsimons, 2019, Ecosystem services in environmental policy: Barriers and opportunities for increased adoption. Ecosystem Services, Vol. 38(June), 100943.

Keputusan Bupati Kabupaten Bantul Nomor 284 Tahun 2014 Tentang Pembagian Area Konservasi Mangrove Baros

Keputusan Bupati Bantul Tahun 2014 Tentang Reservasi Kawasan Konservasi Taman Pesisir. 
Kopnina, H., 2017, Commodification of natural resources and forest ecosystem services: Examining implications for forest protection. Environmental Conservation, Vol. 44, No. 1, hh. 24-33. Le, T. H. T., D.K.Lee, Y.S. Kim, dan Y. Lee, 2016, Public preferences for biodiversity conservation in Vietnam's Tam Dao National Park. Forest Science and Technology, Vol. 12, No. 3, hh. 144-152.

Lin, Y. P., W.C.Lin, Y.C. Wang, W.Y. Lien, T. Huang, C.C. Hsu, N.D. Crossman, 2017, Systematically designating conservation areas for protecting habitat quality and multiple ecosystem services. Environmental Modelling and Software, Vol. 90, hh. 126-146.

Liu, C., dan R. Côté, 2017, A framework for integrating ecosystem services into China's circular economy: The case of eco-industrial parks. Sustainability (Switzerland), Vol. 9, No. 9.

Medellin, R. A., R.Wiederholt, dan L. Lopez-Hoffman, 2017, Conservation relevance of bat caves for biodiversity and ecosystem services. Biological Conservation, No. 211, hh. 45-50.

Moore, A., S.Ndobe, A. Ismi, M. Salanggon, D. Wahyudi, 2015, Biodiversitas dan Isu-Isu Pengelolaan Coral Reefs of Sonit Island, Banggai Archipelago : Biodiversity and Management Issues. hh.1-8.

Mubarok, N. A., A.Mediani, I. Yusuf, dan N Hafidz, 2019, Perancangan Ruang Publik “ Onespot Minimum Space " Berbasis Pengembangan Ruang Terbuka Hijau ( RTH ) yang Berkelanjutan di Universitas Muhammadiyah Surakarta. hh. 23-26.
Mudjia, R., 2017, Studi Kasus Dalam Penelitian Kualitatif: Konsep Dan Prosedurnya. (April), hh. 15-16.

Nuniek, H., 2015, Agritourism Potential As Conservational Effort To Realize Sustainability Development (Case Study in Cinyurup Kampung, Juhut Karangtanjung District, Pandeglang Regency Banten Province).

Peh, K. S. H., I.Thapa, M. Basnyat, A. Balmford, G.P. Bhattarai, R.B. Bradbury, J.C. Merriman, 2016, Synergies between biodiversity conservation and ecosystem service provision: Lessons on integrated ecosystem service valuation from a Himalayan protected area, Nepal. Ecosystem Services, Vol.22, hh 359369.

Peraturan Daerah Kabupaten Bantul No 12 Tahun 2015 Tentang Perlindungan dan Pengelolaan Lingkungan hidup.

Peraturan Bupati Nomor 24 tahun 2016 tentang Konservasi Burung dan Ikan.

Prip, C., 2018, The Convention on Biological Diversity as a legal framework for safeguarding ecosystem services. Ecosystem Services, Vol. 29 (August 2016), hh.199-204.

Purnomo, E. P., dan D. Nurmandi, 2016, Ekologi Pemerintahan: Tata Kelola Dan Kelembaman Birokrasi Dalam Menangani Kebakaran Hutan, Pengelolaan Sawit, Serta Peranan Elit Lokal. hh. i-234. <http://repository.umy. ac.id/handle/123456789/10973>

Rahadian, A. H., 2016, Strategi Pembangunan Berkelanjutan. Prosiding Seminar STIAMI, Vol. II, No. 01, hh. 46-56.

Rahardjo, M., 2018, Studi Fenomenologi Itu Apa? 2. 
Etika Khairina, Eko Priyo Purnomo, Ajree Ducol Malawani -- Sustainable Development Goals: Kebijakan Berwawasan Lingkungan Guna Menjaga Ketahanan Lingkungan Di Kabupaten Bantul

Daerah Istimewa Yogyakarta

Rees, S. E., N.L.Foster, O. Langmead, S. Pittman, dan D.E.Johnson, 2018, Defining the qualitative elements of Aichi Biodiversity Target 11 with regard to the marine and coastal environment in order to strengthen global efforts for marine biodiversity conservation outlined in the United Nations Sustainable Development Goal 14. Marine Policy, Vol. 93(October 2016), hh. 241-250.

Rosana, M., 2018, Kebijakan Pembangunan Berkelanjutan Yang Berwawasan Lingkungan Di Indonesia. Jurnal Ilmu Sosial, Vol. 1, No. 1, hh. 148-163.

Setiawati, T. Wahyu, 2009, Hak, Kewajiban

Dan Peranserta (Partisipasi) Masyarakat Dalam Pengelolaan Lingkungan Hidup. Media Hukum, Vol. IX, No. 2, hh. 12-22. Setyaningrum, E. W., 2017, Pelestarian Mangrove Berbasis Masyarakat Sebagai. hh. 313-321.

Siregar, E., 2007, Kebijakan Pengelolaan Lingkungan Hidup Menurut UndangUndang Nomor 23 Tahun 1997 Di Kota Binjai. h.154.

Temel, J., A. Jones, N. Jones, dan L. Balint, 2018, Limits of monetization in protecting ecosystem services. Conservation Biology, Vol. 32, No. 5, hh. 1048-1062.

Tristyana, E. N., 2018, Pengelolaan sungai code sebagai ekowisata di yogyakarta. (May).

Wahyuningsih, W., 2018, Millenium Develompent Goals (Mdgs) Dan Sustainable Development Goals (Sdgs) Dalam Kesejahteraan Sosial. Bisma, Vol. 11, No. 3, h. 390.

Widyastuti, S., 2019, Sebuah Sintesisi Pada Literatur: Strategi Intervensi
Pemasaran Hijau Menuju Pembangunan Berkelanjutan (A Synthesis of Literature: A Green Marketing Intervention Strategy towards Sustainable Development). JRB-Jurnal Riset Bisnis, Vol. 2, No. 2, hh. 83-94.

Winarna, A., S.Anwar, dan P. Priyanto, 2020, Strategi Pemberdayaan wilayah pesisir dalam menghadapi bencana Tsunami serta Implikasinya terhadap ketahanan wilayah. Jurnal Ketahanan Nasional, Vol. 26, No. 1, hh. 108-131.

Wood, S. L. R., Jones, S. K., Johnson, J. A., Brauman, K. A., Chaplin-Kramer, R., Fremier, A., DeClerck, F. A. 2018 Distilling the role of ecosystem services in the Sustainable Development Goals. Ecosystem Services, Vol. 29, hh. 70-82.

Xu, W., Y.Xiao, J. Zhang, W.Yang, L. Zhang, V. Hull, Z. Ouyang, 2017, Strengthening protected areas for biodiversity and ecosystem services in China. Proceedings of the National Academy of Sciences of the United States of America, Vol. 114, No. 7, hh. 1601-1606.

Yahya, H., 2016, Pendekatan Ekosistem Sebagai Upaya Pengelolaan Kawasan Gumuk Pasir Di Parangtritis Bantul D.I. Yogyakarta, Makalah.

Yustitianingtyas, L., P.Nugini, dan K. Solomon, 2018, Peran Indonesia Dalam Pengelolaan Terumbu Karang. (September 2017), hh. 60-71.

Zhang, L.,Z. Luo, D. Mallon, C. Li, Z. Jiang, 2017, Biodiversity conservation status in China's growing protected areas. Biological Conservation, No. 210, hh. 89-100.

Zhu, D., 2017, Research from global Sustainable Development Goals (SDGs) to sustainability science based on the 
object-subject-process framework.

Chinese Journal of Population

Resources and Environment, Vol. 15, No. 1, hh. 8-20.
Informan

Iswanto

Istiwanto

Agung Budiantoro

\section{Internet}

$<$ www.un.org/susteinabledevelopment $>$

$<$ www.uad.ac.id $>$

$<$ www.dlh.bantulkab.go.id $>$

$<$ www.bapeda.bantulkab.go.id $>$ 